\title{
Desmids of New South Wales: New species and new records
}

\author{
M. Dingley
}

\begin{abstract}
Dingley, M. (Hon. Research Associate, Royal Botanic Gardens, Mrs Macquaries Rd, Sydney, NSW 2000, Australia) 2001. Desmids of New South Wales: new species and new records. Telopea 9(3): 601-637. Five new species are described: Cosmarium decemcrenatum, Cosmarium joadjense, Cosmarium quadricrenum, Cosmarium williamsonii and Staurodesmus applanatus; and fifty-eight new records for New South Wales, of which twenty-seven are newly recorded in Australia, are discussed.
\end{abstract}

\section{Introduction}

Of the 114 or so published references containing Australian desmids (Day et al. 1995 and author's reference collection), only 16 refer to desmids occurring in New South Wales, of which a few mention desmids in a cursory manner such as listing them by genera. The paucity of published records for New South Wales is due in part to the lack of desmid collectors and taxonomists. Playfair, in the early part of the twentieth century $(1907,1908,1910,1912,1914,1915,1917)$ was a major contributor to the description and publication of desmids in New South Wales. Recent papers (Croasdale \& Scott 1976; Ling \& Tyler 1986; Scott \& Prescott 1958; Thomasson 1986) focussed on the tropical north of Australia and others (Prescott \& Scott 1952; Viyakornvilas 1974) concentrated on the south of Australia. Only Skinner (1980) and Dingley (1995) have recently published records from New South Wales. It can be assumed that in the many, non-frequented, freshwater habitats within New South Wales, there lay many new species and new records awaiting to be discovered, identified and recorded. This article describes five proposed new species, and 58 new records for NSW, of which 27 are also new records for Australia. Two taxa are also included as being unusual but without large enough populations to make certain of their diagnoses.

\section{Materials and Methods}

Freshwater samples were collected over a period of several years so that the author could build a database of desmid distribution mainly from areas where no previous collections have been made. With a generous grant from Royal Botanic Gardens Sydney, through the NSW Biodiversity Strategy, some of the results of these studies can now be published.

This research was funded through the NSW Biodiversity Strategy

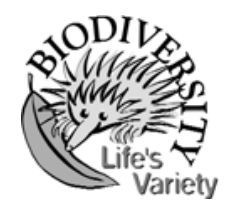


Localities are listed in the Appendix.

Samples were collected mainly by using an extendable hand-held plankton net of hole size $40 \mu \mathrm{m}$, with sweeps being made through submerged littoral macrophytes. Other samples were collected by scraping a green jelly-like substance from wet rocks. Measurements of $\mathrm{pH}$ were made on the spot using a freshly standardised electronic $\mathrm{pH}$ meter, although some samples were not checked. The original samples were preserved in $4 \%$ formalin. The samples were then filtered through a nylon net of hole size $80 \mu \mathrm{m}$ to remove large amounts of detritus. A single drop of sample was placed onto a clean slide and covered using a $22 \times 22 \mathrm{~mm}$ No. 1 cover glass and the edges were sealed using clear nail varnish. Drawings were made using mostly a 100x oil immersion lens and a Nikon drawing tube attached to a Nikon Optiphot 2 microscope. I made most determinations with reference to Croasdale et al. (1994) and Prescott et al. $(1975,1977,1981,1982)$, Ruzicka $(1977,1981)$ and Ling and Tyler $(1986)$. These are the most recent whole-group treatments. The order in which the genera are treated is that in Croasdale \& Flint (1986): Closterium, Haplotaenium, Pleurotaenium, Tetmemorus, Euastrum, Micrasterias, Actinitaenium, Cosmarium, Xanthidium, Staurodesmus, Staurastrum, Teilingia, Spondylosium, Hyalotheca.

\section{Explanation of symbols and abbreviations}

L. = Length

L. csp. = Length with spines

L. ssp. = Length without spines

Br. = Breadth

Br. csp. $=$ Breadth with spines

Br. ssp. $=$ Breadth without spines

Br. cpr. $=$ Breadth with processes

Isth.= Isthmus

Ap.= Breadth of apices

Ap. csp. = Apice with spines

L.:Br. = ratio of length to breadth

Th. $=$ Thickness

${ }^{\circ}$ Arc $=$ curvature in degrees

\section{Taxonomic results}

\section{Family Closteriaceae}

CLOSTERIUM Nitzsch ex Ralfs

Closterium didymotocum (Corda) Ralfs

Croasdale \& Flint 1986, p. 58, pl. 9, figs 13, 14.

L. $499.0 \mu \mathrm{m}$, Br. $51.7 \mu \mathrm{m}$, Ap. 13.2, ${ }^{\circ}$ Arc ca. $15^{\circ}$ L.:Br. 9.6. (Fig. 13b).

Cell walls had about 10 striations in $10 \mu \mathrm{m}$, all of which were covered with punctae along their length and becoming more prominent towards the apices. All cells had orange/brown walls. 
Locality: Site 1.

Distribution: Widely distributed throughout North America, Great Britain, Europe, Asia, New Zealand, Africa, South America, Faeroes and the Arctic; a new record for Australia.

Closterium intermedium Ralfs var. intermedium

Croasdale \& Flint 1986, p. 61, pl. 9, fig. 11-15.

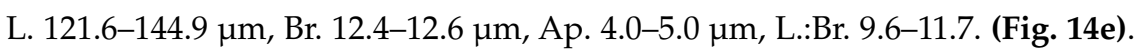

Cells moderately curved, approx. $35^{\circ}$ Arc and not inflated in the mid region. The truncate poles had an inner thickening of the wall and most cells were yellowish brown in colour.

Locality: Site 2.

Distribution: Previously recorded from the Northern Territory, Queensland and Victoria (Bailey 1898, 1913, Gibbons 1874, McLeod 1975, Schmidle 1896, Thomasson 1986). Playfair (1917) recorded Cl. intermedium var. hibernicum West et G.S. West from New South Wales which is smaller, has smaller L.:Br. but more striae; a new record for New South Wales.

Closterium navicula (Bréb.) Lütkem.

Croasdale \& Flint 1986, p. 65, pl. 4, figs 9, 10.

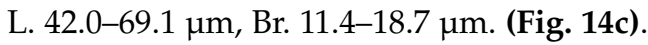

Specimens slightly variable in shape as well as size. From sites with a variation in $\mathrm{pH}$ of 5.8 to 9.3 , showing this taxon is tolerant of a wide range of acidity.

Localities: Sites 3, 4 \& 5 .

Distribution: Previously recorded from the Northern Territory and Queensland (McLeod 1975, Thomasson 1986, West 1912); a new record for New South Wales.

Closterium ralfsii Bréb. var. hybridum Rabenh.

Ling \& Tyler 1986, p. 18, pl. 7, fig. 2.

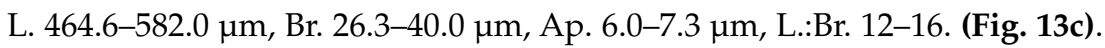

Although these algae agree with the description in Ling \& Tyler (1986) many of the specimens differed from the typical in that the striae were composed of fine punctae.

Locality: Site 2.

Distribution: Previously recorded from the Northern Territory by Ling \& Tyler (1986), Scott \& Prescott (1958) and Thomasson (1986); a new record for New South Wales.

Closterium strigosum Bréb. var. strigosum

Croasdale \& Flint 1986, p. 69, pl. 8, figs 1, 2.

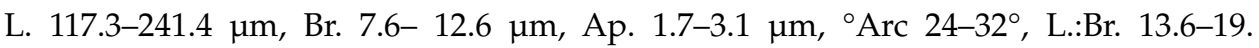
(Fig. 14b).

Cells not inflated in the mid-region but incurved gradually towards the apical region.

Localities: Sites 7, 8 \& 9.

Distribution: North America, Great Britain and Europe; a new record for Australia. 
Closterium strigosum var. elegans G.S. West

Ruzicka1977, p. 176, pl. 22, figs 1-11.

L. $256.3 \mu \mathrm{m}$, Br. $14.3 \mu \mathrm{m}$, Ap. $2.5 \mu \mathrm{m}$, L.:Br. 17.9. (Fig. 13a).

Apices more produced than that in the typical, more incurved and the mid-region of the cells more pronounced. Although no striations were visible the cell wall was granular.

Locality: Site 10.

Distribution: North America, Great Britain, Europe, Africa and the Arctic; a new record for Australia.

Closterium subscoticum Gutw.

Ruzicka 1977, p. 179, pl. 22, figs 12-18.

L. 331.8-421.1m, Br. 12.7-14.4m, Ap. 8.8-9.4m, L.:Br. 25-33. (Fig. 14a).

Most cells in this sample fell within the normal cell size range (a few were slightly larger) but all had a slight apical swelling. Some cell walls were smooth or had exceedingly fine striations only just seen using an $100 \times$ oil immersion objective. Some individuals had punctae associated with fine striae which became fainter until they disappeared towards the apices. Apical vacuoles contained a single crystal.

Locality: Site 11.

Distribution: Previously recorded from the Northern Territory (Thomasson 1986); a new record for New South Wales.

Closterium venus Kütz. var. westii Willi Krieg.

Croasdale \& Flint 1986, p. 70, pl. 5, figs 16,17.

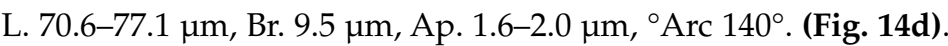

This is a less curved variety than the typical and agrees with Croasdale \& Flint 1986. Cells contained two pyrenoids per semicell and a conspicuous end pore.

Locality: Site 12.

Distribution: North America, Europe, Asia, New Zealand; a new varietal record for Australia.

\section{Family Desmidiaceae}

HAPLOTAENIUM Bando

Haplotaenium minutum (Ralfs) Delponte var. cylindricum (Borge) Sormus

Sormus 1996, p. 11, fig. 5.

Pleurotenium minutum Ralfs (Sormus 1996).

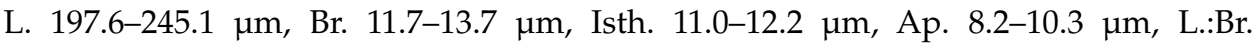
15.2-18.5. (Fig. 12a).

Cells were slightly tapered with strongly rounded apices. Most cells had a slight degree of curvature, usually in one semicell.

Locality: Site 11.

Distribution: North America, Brazil; a new varietal record for Australia. 


\section{PLEUROTAENIUM Nägeli}

Pleurotaenium eugeneum (W.B. Turner) West et G.S. West var. undulatum (Borge) Willi Krieg.

Prescott et al. 1975, p. 118, pl. 47, fig. 13.

L. (semicell) $502.2 \mu \mathrm{m}$ (total length $1004.4 \mu \mathrm{m}$ ), Br. $59.7 \mu \mathrm{m}$, Ap. $49.3 \mu \mathrm{m}, \mathrm{L} .: B r .16 .8$. (Fig. 12c).

A single empty semicell was found in this sample. The cell wall contained pores inside of which were small pits. There were 12 apical tubercles and about 18 undulations along the length of the semicell.

Locality: Site 13.

Distribution: Alaska; a new record for Australia.

Pleurotaenium kayei (W. Archer) Rabenh.

Ling \& Tyler 1986, p. 36, pl. 10, figs 7-8.

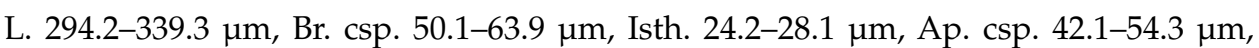
L.:Br. 5.2-6.4. (Fig. 12d).

The semicells contained four whorls of paired spines (contrary to the five reported in the protologue of Docidium kayei, but in agreement with the cells illustrated). This taxon was common in the sample.

Locality: Site 11.

Distribution: Previously recorded from the Northern Territory (Croasdale \& Scott 1976, Ling \& Tyler 1986, Scott \& Prescott 1958, Thomasson 1986); a new record for New South Wales.

Pleurotaenium sceptrum (Roy) West et G.S. West

Prescott et al. 1975, p. 130, pl. 42, figs 3-10.

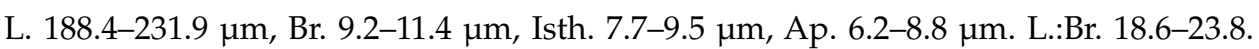
(Fig. 12b).

This taxon was very common in the sample. Some specimens had a smooth cell wall while others were finely punctate. The four apical spines are very small $(0.85-1.1 \mu \mathrm{m}$ long).

Locality: Site 11.

Distribution: Previously recorded from the Northern Territory by Ling \& Tyler (1986) as P. sceptrum forma; a new record for New South Wales.

Pleurotaenium subcoronulatum (W.B. Turner) West et G.S. West var. subcoronulatum

Ling \& Tyler 1986, p. 37, pl. 12, figs 12, 13, 19-24.

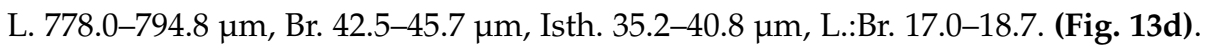

Three slight undulations below the basal inflation were evident and there were 3-4 slight undulations just below the apex. Each cell contained 10 apical tubercles as well as a prominent isthmal ring. Cell morphology is consistent with that reported by Ling and Tyler 1986 (p. 37) although they also reported 'the plants characteristically form short filaments'; no such filaments were seen in this sample. The length of these algae places them near $P$. subcoronulatum var. subcoronulatum $\mathrm{f}$. elongatum Croasdale \& Scott but they differ in having a smaller L:Br. 
Locality: Site 14.

Distribution: Previously recorded from the Northern Territory (Ling \& Tyler 1986, Thomasson 1986); a new record for New South Wales.

Pleurotaenium truncatum (Bréb.) Nägeli var. farquharsonii (Roy) West et G.S. West.

Ruzicka 1977, p. 285, pl. 43, figs 6-9.

L. 331.7-383.8 (608.0) $\mu \mathrm{m}$, Br. 31.6-33.9 (40.4) $\mu \mathrm{m}$, Isth. 28.1-29.2 (39.7) $\mu \mathrm{m}$, Ap. 18.2-20.5 (26.7) $\mu \mathrm{m}, \mathrm{L} .: B r .10 .4-14.3$. (Fig 12e).

Semicells were less tumid with a more prominent basal inflation and slightly concave below the apex than the nominal. Most specimens fell within the normal range of measurements, however two specimens were larger, being L. 576.8 \& $608.0 \mu \mathrm{m}$, Br. 40.4 \& $46.2 \mu \mathrm{m}$, Isth. $33.1 \& 39.7 \mu \mathrm{m}$, Ap. 24.8-26.7 $\mu \mathrm{m}$.

Locality: Site 2.

Distribution: North America, Great Britain, Europe; a new varietal record for Australia.

TETMEMORUS Ralfs

Tetmemorus brebissonii (Menegh.) Ralfs var. tenuissimus K. Möbius

Scott \& Prescott 1961, p. 21, pl. 6, fig. 6.

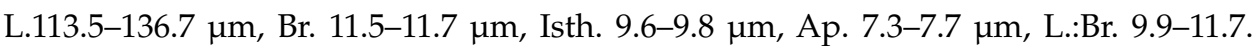
(Fig. 6h).

Cells contained 2-4 pyrenoids in each semicell and the cell walls had faint and finely discernable punctae which were scattered rather than in rows.

Locality: Site 11.

Distribution: Previously recorded from the Northern Territory and Queensland (Bailey 1893, 1913, Möbius 1892, 1895, Scott \& Prescott 1958); a new varietal record for New South Wales.

EUASTRUM Ehrenberg ex Ralfs

Euastrum ansatum Ehrenb. Ex Ralfs var. dideltiforme F. Ducell.

Prescott et al. 1977, p. 17, pl. 59, fig. 15.

L. $84.3 \mu \mathrm{m}$, Br. $40.1 \mu \mathrm{m}$, Isth. $12.0 \mu \mathrm{m}$, L.:Br. 2.1. (Fig. 7h)

A variety with the basal angles more sharply rounded than the species type. Low, rounded lateral lobes with the margins of the polar lobe sub-parallel to the flattened apex. The median notch was relatively narrow and the face of some semicells showed a mucilage pore, although they were quite difficult to discern in some individuals.

Locality: Site 13.

Distribution: Previously recorded from the Northern Territory, South Australia and Queensland (Croasdale \& Scott 1976, McLeod 1975, Prescott \& Scott 1952, Thomasson 1986); a new varietal record for New South Wales.

Euastrum insulare (Wittr.) Roy var. insulare

Croasdale \& Flint 1986, p. 92, pl. 23, figs 3-5.

L. $19.2 \mu \mathrm{m}$, Br. $15.5 \mu \mathrm{m}$, Isth. $5.2 \mu \mathrm{m}$, L.:Br. 1.2. (Fig. 7f) 
Cells were similar to those in all references studied.

Locality: Site 2.

Distribution: Previously recorded from Victoria (Darling 1982, Hardy 1931-1956); a new record for New South Wales.

Euastrum insulare var. silesiacum (Grönblad) Willi Krieg.

Ruzicka 1981, pl. 72, figs 11 \& 13.

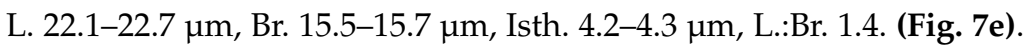

Cells differ from the typical in not having the blunt spine-like thickening on the apical angles, were shorter and relatively broader and the basal margins were slightly divergent. This taxon fits the description in Ruzicka (1981), but of the five figures shown (9-13), only figures $11 \& 13$ are representative of the organisms in this sample.

Locality: Site 13.

Distribution: Europe, Russia; a new varietal record for Australia.

Euastrum praemorsum (Nordst.) Schmidle forma

Croasdale \& Flint 1986, p. 95, pl. 20, fig. 7.

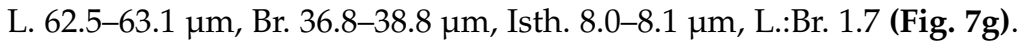

The apices were convex with a deep open notch. There was also a large smooth basal protuberance under two scrobiculi, and two small protuberances at the base of the polar lobe.

Locality: Site 13.

Distribution: Previously recorded from the Northern Territory and Queensland (Croasdale \& Scott 1958, Ling \& Tyler 1986, McLeod 1975, Scott \& Prescott 1958, Thomasson (1986), Scott 1954); a new record for New South Wales.

MICRASTERIAS C.A. Agardh ex Ralfs

Micrasterias sp. Pl. fig.

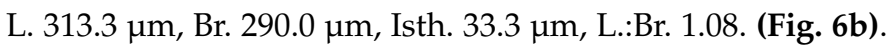

This taxon is close to M. apiculata var. fimbriata f. fimbriata (Ehrenb.) ex Ralfs but differs from it in having an extramarginal spine just below the apex of the apical lobe instead of a single spine on either side of the apical notch. There was also a single medially placed isthmal spine on each semicell. Designated an unknown taxon until more specimens can be examined.

Locality: Site 11.

Micrasterias rotata (Grev.) Ralfs var. rotata f. evoluta W.B. Turner

Prescott et al. 1977, p. 186, pl. 134, figs 1-4.

L. $215.8 \mu \mathrm{m}$, Br. $208.4 \mu \mathrm{m}$, Isth. $31.9 \mu \mathrm{m}, \mathrm{L} .: B r .1 .03$. (Fig. 6a).

Specimens in the sample were observed having the polar lobe supporting bidentate angles as well as the single spine on either side of the apical notch. A few specimens were seen with a single spine on the polar lobe extremities. Prescott et al. (1977, p. 186) consider this form to be of uncertain rank as the spine on either side of the apical notch is a variable feature. It should be compared with M. apiculata var. fimbriata (Ralfs) Nordst., from which it differs in having less open incisions and shorter terminal teeth. 
Locality: Site 13.

Distribution: Previously recorded as the nominal variety in Anon (1946), Croasdale \& Scott (1976), Harrop (1869), Playfair (1917) and as the var. simplicior Scott et Prescott in Scott \& Prescott (1958); a new form for Australia.

Micrasterias zeylanica Fritsch var zeylanica

Croasdale \& Flint 1986, p. 109, pl. 24, figs 3-4.

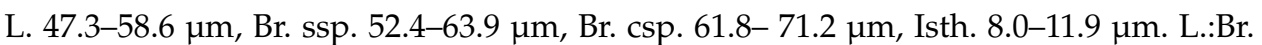
0.75-0.82. (Fig. 6i).

This taxon was quite common in the sample and there appeared to be several forms differing in the structure of the apical lobes; the more common form bore no spines on the upper corner of the apical corners. One individual contained a spine at this point and another was an intermediate form having this spine on both lateral lobes on one semicell and none on the opposite semicell.

Locality: Site 13.

Distribution: Previously recorded from the Northern Territory, Queensland and Tasmania (Croasdale \& Scott 1976, Grimes 1988, McLeod 1975, Scott \& Prescott 1958, Thomasson 1986, Tyler 1970); a new record for New South Wales.

ACTINOTAENIUM (Nägeli) Teiling

Actinotaenium cucurbitinum (Bisset) Teiling var. subpolymorphum (Nordst.) Teiling Prescott et al. 1981, p. 12, pl. 151, fig. 13.

L. $69.1 \mu \mathrm{m}$, Br. $29.9 \mu \mathrm{m}$, Isth. $28.5 \mu \mathrm{m}$. L.:Br. 2.3. (Fig. 6j).

This taxon differs from the nominal variety in its cells being relatively broader and about 2.3 times longer than broad.

Locality: Site 11.

Distribution: North America, South America, New Zealand, Africa; a new varietal record for Australia.

COSMARIUM Corda ex Ralfs

Cosmarium biretum (Bréb.) Ralfs

Prescott et al. 1981, p. 83, pl. 277, fig. 10.

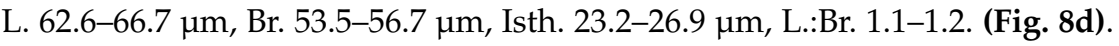

Although very similar to that in Prescott et al. (1981: Pl. 277, fig. 10) these algae, when observed in end view, were elliptical with a slight median swelling. In side view they were circular and slightly thickened medially giving an appearance very similar to the var. intermedia Wille.

Locality: Site 1.

Distribution: Recorded (but not illustrated) from Victoria by Hardy (1905) and Nordstedt (1888); a new record for New South Wales.

Cosmarium blyttii Wille var. blyttii

Croasdale \& Flint 1988, p. 55, pl. 47, figs 14-15.

L. $18.4 \mu \mathrm{m}$, Br. $15.8 \mu \mathrm{m}$, Isth. $5.2 \mu \mathrm{m}$, Th. $9.0 \mu \mathrm{m}$, L.:Br. 1.1. (Fig. 9c). 
The cells showed only slightly flattened apical crenae, with one or two rows of intramarginal granules. The central papilla was very evident in side view.

Locality: Site 2.

Distribution: Previously recorded from Northern Territory, South Australia, Queensland and Victoria. Playfair $(1914,1915,1917)$ recorded C. blyttii var. lismorense Playfair and C. blyttii var. casinoense Playfair from New South Wales; a new record for New South Wales.

\section{Cosmarium cymatonotophorum West}

Prescott et al. 1981, p. 117, pl. 279, fig. 6.

L. $9.3 \mu \mathrm{m}$, Br. $9.2 \mu \mathrm{m}$, Isth. $3.5 \mu \mathrm{m}$, L.:Br. 1.0. (Fig. $8 \mathbf{b}$ ).

The sinuses were not as widely open and cells were slightly smaller than those shown in Prescott et al (1981).

Locality: Site 15.

Distribution: Alaska, United Kingdom, Europe, Asia, South America; a new record for Australia.

\section{Cosmarium decemcrenatum $M$. Dingley sp. nov.}

Cellulae $46.0-52.3 \mu \mathrm{m} \times 37.5-42.3 \mu \mathrm{m}, 16.6-17.8 \mu \mathrm{m}$ late isthmo, 26.3-29.2 $\mu \mathrm{m}$ crassae, 1.2-1.23 plo longiores quam latiores; sinus anguste linearis. Semicellulae late truncatopyramidales angulis rotundatis et marginibus convexis, apice nonnihil complanatis; margines crenis 9-10 rotundatis et apices crenis 4-6 minoribus praediti; granula in seriebus 2-4 concentricis intramarginalibus disposita atque granulis multo minoribus in area centrali dispersis. Semicellulae a latere visae subcirculares, granulis in seriebus $2-4$ intramarginalibus, area centrali laevi sed interdum granulis paucis parvis et vix distinguibilibus; ab extremo visae ellipticae, granulis $2-4$ intramarginalibus atque area centrali laevi.

Holotype: Figure 1.

Collection locality: Joadja Creek, 11 km north-west of Berrima, 34²4'23"S, 150¹9'21"E, $700 \mathrm{~m}$ asl. Ephemeral, oligotrophic water body, mostly turbid, and with few aquatic plants. Along one edge of the pool is a small stand of Eleocharis sp., pH 7.8, 22 Aug 1992.

Material containing this taxon has been deposited at NSW.

Cells 1.2-1.23 times longer than broad. Sinus narrowly linear; semicells broadly truncate pyramidal, with rounded angles, convex sides and somewhat flattened apex; sides with 9-10 rounded crenae, 4-6 smaller crenae on apex; granules in 2-3 concentric rows within the margins, scattered and much smaller granules in the central area. Side view sub-circular showing 2-4 rows of intramarginal granules, central area smooth, sometimes showing a reduced number of small hardly discernable granules. End view, elliptic with about 32 marginal granulations, 2-4 rows of intramarginal granules and a smooth central area.

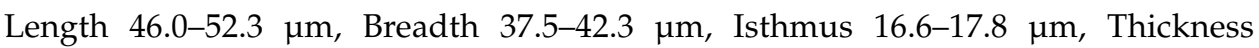

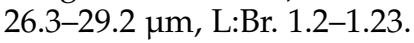

Notes: This taxon appears at first glance to be similar to C. quadrum P. Lundell var. quadrum which is oblong-elliptic in end view with straight parallel sides, whereas this new taxon is elliptic in end view. In face view there is an appreciable difference in the number of intramarginal rows of granules giving rise to an almost smooth central area. 


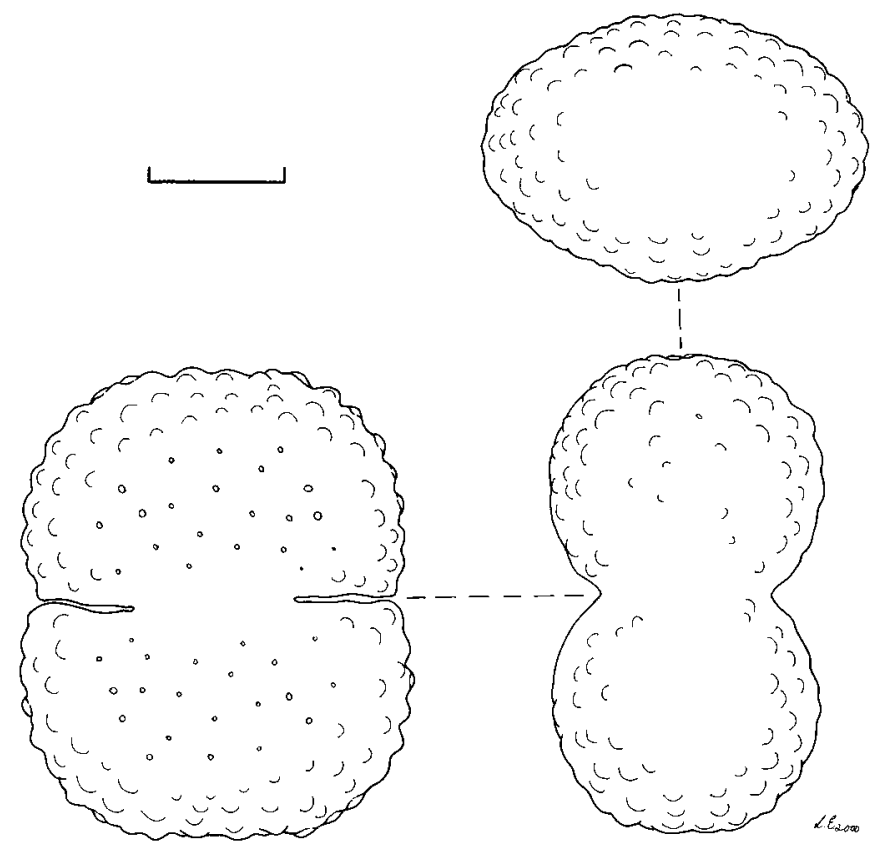

Fig. 1. Holotype of Cosmarium decemcrenatum M. Dingley. Scale bar $=10 \mu \mathrm{m}$.

Cosmarium depressum (Nägeli) P. Lundell var. depressum f. minutum (Heimerl) Kreiger et Gerloff

Ling \& Tyler 1986, p. 21, pl. 15, figs 11-12.

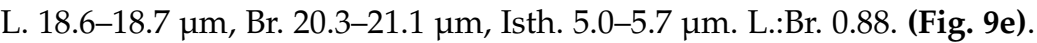

All specimens were surrounded by a mucilage envelope.

Locality: Site 13.

Distribution: Previously recorded from the Northern Territory (Ling \& Tyler 1986); a new record for New South Wales.

Cosmarium dorsitruncatum (Nordst.) G.S. West

Croasdale \& Flint 1988, p. 65, pl. 33, fig. 20.

L. $28.8 \mu \mathrm{m}$, Br. $35.0 \mu \mathrm{m}$, Isth $13.7 \mu \mathrm{m}$, Th. $16.4 \mu \mathrm{m}$, L.:Br. 0.82. (Fig. 9b).

Specimens were only slightly flattened at the apex, the cell walls were punctate and each semicell contained two pyrenoids. This was first thought to be $C$. depressum (Nägeli) P. Lundell from which it differs in having two pyrenoids instead of one and having less rounded basal angles.

Locality: Site 11.

Distribution: Previously recorded from Victoria (West 1909); a new record for New South Wales. 


\section{Cosmarium isthmium West}

Prescott et al. 1981, p. 163, pl. 243, fig. 6.

L. 46.6-48.2 $\mu \mathrm{m}$, Br. 28.4-29.8 $\mu \mathrm{m}$, Isth. 13.1-14.0 $\mu \mathrm{m}$. L.:Br. 1.6. (Fig. 8c).

There is some confusion in the literature between C. isthmium and C. excavatum f. duplo-major P. Lundell (see Kouwets 1997, p. 44 under C. horizontale (Schmidle) Kouwets and also Prescott et al. 1981, p. 163). The cells here have a wider and deeper constriction than $C$. excavatum, with more granules and are about half the size. They are consistent with the species as circumscribed by West \& West (1908, p. 145, pl. 77, figs 7-10).

Locality: Sites 16, 17.

Distribution: Widely distributed in North America, United Kingdom, Europe, Africa, Arctic; a new record for Australia.

Notes: found at two sites, one with $\mathrm{pH}$ of 7.3 and the other a staggering 10.3 indicating that this taxon can withstand a wide range of alkalinity.

\section{Cosmarium joadjense $M$. Dingley sp. nov.}

Cellulae mediocres 32.5-33.5 $\mu \mathrm{m} \times 28.2-28.9 \mu \mathrm{m}, 9.6-10.5 \mu \mathrm{m}$ late isthmo, 18.2-18.9 $\mu \mathrm{m}$ crassae, 1.15-1.16 plo longiores quam latiores; sinus profundus linearisque. Semicellulae truncato-pyramidales angulis basalibus rotundatis 2-3-crenatis tum retusis apicem versus; semicellula seriem unicam intramarginalem crenarum praebens et crena unica intramarginali in angulis; paries cellulae subtiliter punctatus. Semicellulae a latere visae circulares utraeque crena subapicali instructae undulationibus minoribus inter se, ab extremo visae ellipticae, crenas 4 terminales gerentes, duobus externis quam duobus marginalibus maioribus. Pyrenoides unica per semicellulam.

\section{Holotype: Figure 2.}

Collection locality: Joadja Creek, 11 km north-west of Berrima, 34²4'23"S, 150¹9'21"E, $700 \mathrm{~m}$ asl. Ephemeral, oligotrophic water body, mostly turbid, and with few aquatic plants. Along one edge of the pool is a small stand of Eleocharis sp., pH 7.8, 22 Aug 1992.

Material containing this taxon has been deposited at NSW.

Cells of medium size, sinus deep and linear; semicells truncate pyramidal, the basal angles rounded with 2-3 crenations and then retuse towards the apex. A single row of intramarginal crenae are found within the marginal crenae. The corners of the apex bear a single intramarginal crena. Cell wall is finely punctate. Side view semicells circular bearing a large sub apical crena between which are smaller undulations. The rest of the cell wall in finely punctate. End view broadly elliptical bearing four crenae on the ends, the largest of which are the two outer ones with two marginal crenae on either side of the mid region.

There is a single pyrenoid in each semicell. Length 32.5-33.5 $\mu \mathrm{m}$, Breadth 28.2-28.9 $\mu \mathrm{m}$, Isthmus 9.6-10.5 $\mu \mathrm{m}$, Thickness 18.2-18.9 $\mu \mathrm{m}, \mathrm{L.:Br}$. 1.15-1.16.

Notes: This taxon resembles C. hexapappillatum Jao and C. hexapappillatum var. novempappillatum $\mathrm{Zhu} \& \mathrm{Hu}$ but differs from them in having a wider isthmus, the lateral wall more undulated and without the papillae on face, side and end views. 


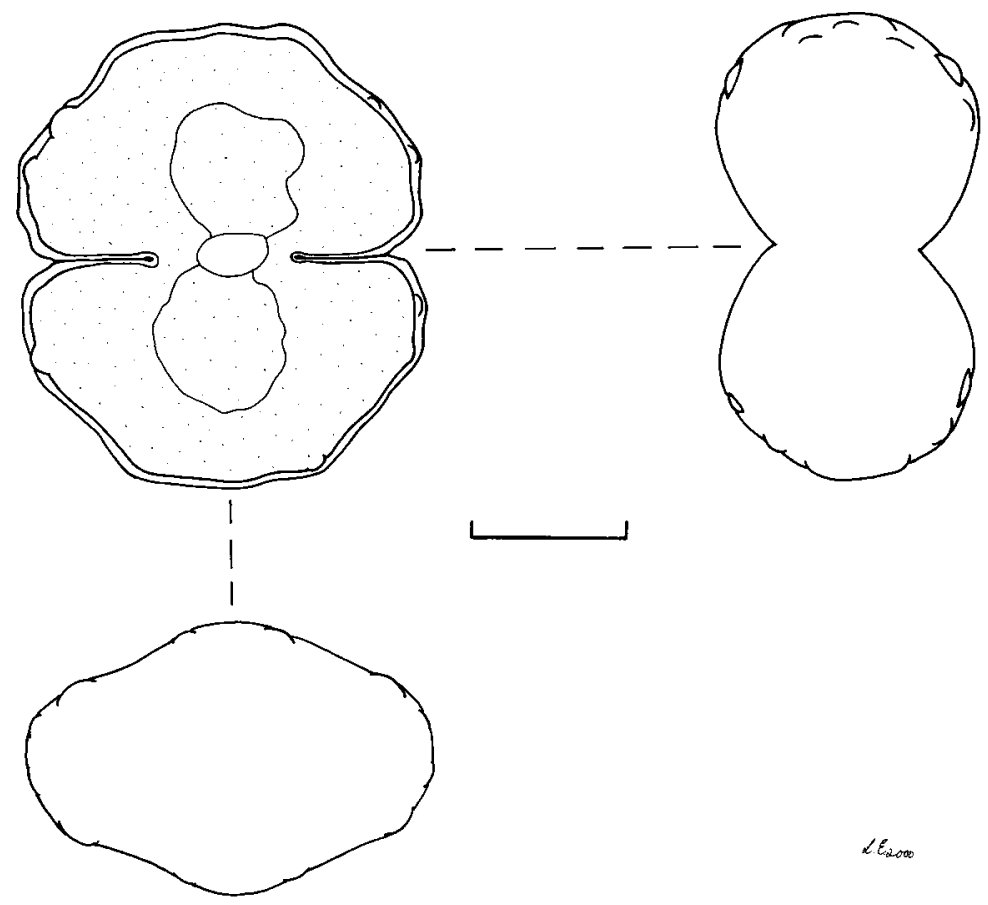

Fig. 2. Holotype of Cosmarium joadjense M. Dingley. Scale bar $=10 \mu \mathrm{m}$.

Cosmarium margaritatum (P. Lundell) Roy et Bisset

Croasdale \& Flint 1988, p. 74, pl. 52, figs 7-8.

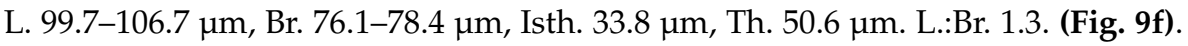

This taxon is characterised with each granule being surrounded by six punctae in the form of a hexagon.

Locality: Site 11.

Distribution: Previously recorded from the Northern Territory, South Australia and Victoria (Prescott \& Scott 1952, Thomasson 1986, Watts 1887 (as Cos. margaritaceum ); a new record for New South Wales.

\section{Cosmarium obtusatum Schmidle}

Croasdale \& Flint 1988, p. 81, pl. 36, figs 14-16.

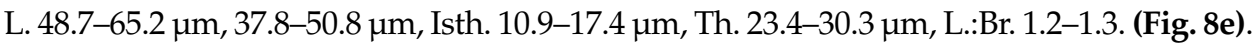

Cells contained about 7-9 undulations on margins, two rows of intramarginal undulations which resembled granules, and two pyrenoids per semicell.

Locality: Site 18.

Distribution: Widely distributed in North America, United Kingdom, Europe, Asia, South and Central America, New Zealand, Arctic; a new record for Australia. 


\section{Cosmarium pachydermum P. Lundell}

Croasdale \& Flint 1988, p. 83, pl. 30, figs 1, 3.

L. $79.3 \mu \mathrm{m}$, Br. $64.3 \mu \mathrm{m}$, Isth. $25.0 \mu \mathrm{m}$, L.:Br. 1.2. (Fig. 9a).

Cells were consistent with Croasdale \& Flint (1988), but were at the lower end of the size range.

Locality: Site 13.

Distribution: Previously recorded from the Northern Territory, Queensland, Victoria (Bailey 1898, 1913; Borge 1896; Grimes 1988; Hardy 1905; Ling \& Tyler 1986; McLeod 1975; Schmidle 1896; Scott \& Prescott 1958; Thomasson 1986); a new record for New South Wales.

\section{Cosmarium punctulatum Bréb.}

Prescott et al. 1981, p. 254, pl. 235, fig. 1.

L. $17.7 \mu \mathrm{m}$, Br. $16.4 \mu \mathrm{m}$, Isth. $6.6 \mu \mathrm{m}$, Th. $10.1 \mu \mathrm{m}$. L.:Br. 1.08. (Fig. 9d).

These organisms differ from the above description by the size which were about half the dimensions. This taxon matches 'var. minor Oye et Cornil' but according to Prescott et al. (1981) the variety was published without a Latin diagnosis and should be reduced to synonymy with the typical unless some feature other than size is recorded.

Locality: Site 19.

Distribution: Quebec, Europe; a new varietal record for Australia.

Cosmarium quadratum Ralfs var. willei (Schmidle) Willi Krieg. et Gerloff

Croasdale \& Flint 1988, p. 83, pl. 38, fig. 15.

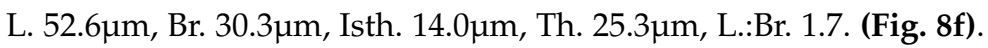

In face view the sides of the semicells were slightly convex without a protruding basal angle as in the typical, and also becoming slightly broader towards the apex. The cell wall contained dense punctae appearing as dashes rather than as circles.

Locality: Site 20.

Distribution: Widespread in United Kingdom, Europe, Asia, North and South America, New Zealand; a new record for Australia.

Cosmarium quadricrenum $M$. Dingley sp. nov.

Cellulae mediocres 32.7-34.4 $\mu \mathrm{m} \times 29.2-30.1 \mu \mathrm{m}, 9.6-12.5 \mu \mathrm{m}$ late isthmo, $16.3-17.7 \mu \mathrm{m}$ crassae, parum longiores quam latiores, constrictione mediano profundo, lineari reconditoque; isthmus angustus. Semicellulae truncato-pyramidales apice paulo complanato undulatoque; parietes cellulae paulo undulati undulationibus 4 utroque marginis tum serie unica consentanea intramarginali undulationis, superficie cetero laevi. Semicellulae a latere visae subcirculares granulo prominenti subterminali utroque apicis, ab extremo visae late ellipticae.

Holotype: Figure 3.

Collection locality: Joadja Creek, 11 km north-west of Berrima, 34²4'23"S, 150¹9'21"E, $700 \mathrm{~m}$ asl. Ephemeral, oligotrophic water body, mostly turbid, and with few aquatic plants. Along one edge of the pool is a small stand of Eleocharis sp., pH 7.8, 22 Aug 1992.

Material containing this taxon has been deposited at NSW. 
Cells of medium size, slightly longer than broad, median constriction deep, linear and closed, isthmus narrow; semicells truncate pyramidal with a slightly flattened and slightly undulate apex which also appears slightly proud, walls slightly undulate having four or five undulations on each side of the semicell margin; a single row of intramarginal undulations following the same formation as the marginal ones lead into a smooth face of the semicell; side view semicells sub circular with a single but prominent granule on either side of and just below the apex; end view broadly elliptic.

Length 32.7-34.4 $\mu \mathrm{m}$, Breadth 29.2-30.1 $\mu \mathrm{m}$, Isthmus 9.6-12.5 $\mu \mathrm{m}$, Thickness 16.3-17.7 $\mu \mathrm{m}$ L.:Br. 1.08-1.17

Notes: This plant resembles Cosmarium sp. in Croasdale \& Scott (1976, Pl. 7 fig. 7) who were unable to identify it because they had incomplete material. It also resembles $C$. sublatere-undatum West et G.S. West (1895, p. 60, Pl. 8:1) and C. dispersum L. N. Johnson (1895, p. 297, Pl. 233:19) but differs from both in being more depressed, having fewer crenulations and with a more prominent central tumour which is noticeable in end view. Croasdale \& Scott (1976) in their figure, show the semicells having two rows of intramarginal crenulations and in side view having two noticeable granules on the margins of the semicells. This new taxon has only a single row and one marginal granule on each half of the semicell.

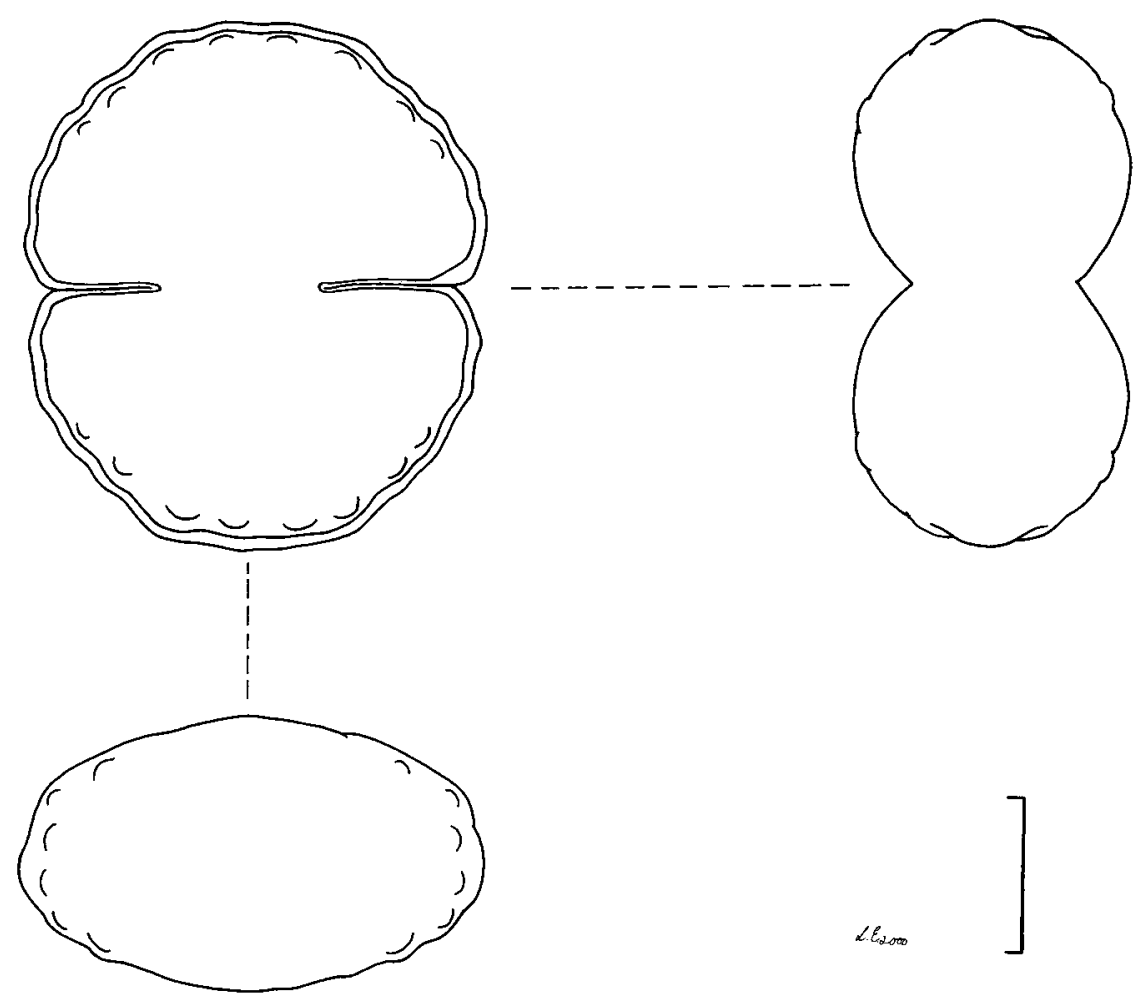

Fig. 3. Holotype of Cosmarium quadricrenum M. Dingley. Scale bar $=10 \mu \mathrm{m}$. 
Cosmarium quadriverrucosum West et G.S. West var. supraornatum Skuja

Croasdale \& Flint 1988, p. 95, pl. 45, figs 3-5.

L. $26.9 \mu \mathrm{m}$, Br. $24.7 \mu \mathrm{m}$, Isth. $6.8 \mu \mathrm{m}$, Th. $20.2 \mu \mathrm{m}$, L.:Br. 1.2. (Fig. 8g).

The two central tumours were composed of 6-7 granules. In lateral view the semicells were circular and showed about three prominent median granules. Skuja's (1976) drawing on Pl. 11, fig. 14 in face view is somewhat flattened and with a more flattened apex than the individuals in this sample.

Locality: Site 21.

Distribution: Asia (Burma), New Zealand; a new record for Australia.

Cosmarium quadrum P. Lundell var. sublatum (Nordst.) West et G.S. West

Prescott et al. 1981, p. 264, Pl. 283, fig. 7.

L. $63.1 \mu \mathrm{m}$, Br. $61.2 \mu \mathrm{m}$, Isth. $18.9 \mu \mathrm{m}$, L.:Br. 1.0. (Fig. 8h).

This taxon differs from the nominal in having six punctae surrounding each granule and each cell with divergent sides.

Locality: Site 22.

Distribution: North America, Europe, Africa, Arctic; a new record for Australia.

Cosmarium regnesii Reinsch var. montanum Schmidle

Lenzenweger, 1989, p. 103, pl. 2, fig. 24.

L. $12.5 \mu \mathrm{m}$, Br. $11.4 \mu \mathrm{m}$, Isth. $5.2 \mu \mathrm{m}$, Th. $6.8 \mu \mathrm{m}$, L.:Br. 1.1. (Fig. 8a).

This is the first time that the author has seen this species and the material examined is referred to var. montanum on the basis of cell size and the three facial protuberances, although the central protuberance in face view was difficult to observe. The protuberance became clearer in lateral and vertical views. Prescott et al. (1981) in their plate 258 fig. 3 show a very similar drawing to this but have placed it as the typical. It would seem that there is variation within populations (Prescott et al. ibid.) and a more detailed examination is required on these algae.

Locality: Site 23.

Distribution: Previously recorded from Queensland (Bailey 1898, 1913, McLeod 1975, Schmidle 1896); a new record for New South Wales.

\section{Cosmarium subundulatum Wille}

Prescott et al. 1981, p. 317, pl. 168, figs 2-6.

L. $36.3 \mu \mathrm{m}$, Br. $28.4 \mu \mathrm{m}$, Isth. $9.8 \mu \mathrm{m}$, Th. $19.2 \mu \mathrm{m}$, L.:Br. 1.3-1.4. (Fig. 8i).

This taxon agrees with Prescott et al. (1981) pl. 168 figs 2-6. Semicells when viewed in end view were elliptic, in lateral view ovate, with both views showing a broad median tumour. There were two pyrenoids in each semicell.

Locality: Site 24.

Distribution: North America, United Kingdom, Europe, Asia, South America, Arctic; a new record for Australia. 


\section{Cosmarium williamsonii $M$. Dingley sp. nov}

Cellulae mediocres 36.2-38.1 $\mu \mathrm{m} \times 33.0-33.7 \mu \mathrm{m}, 8.5-10.7 \mu \mathrm{m}$ late isthmo, 20.0-21.4 $\mu \mathrm{m}$ crassae, 1.09-1.13 plo longiores quam latiores; sinus profundus linearisque. Semicellulae semicirculares; crenae laterales 4, apicales 2, serie unica consentanearum intramarginalium crenarum, pariete cetero subtiliter punctato; crenae marginales prope apicem plus prominentes. Semicellulae a latere visae subcirculares crenas apicales apicali-intramarginalesque praebentes, ab extremo visae late ellipticae crenis marginalibus 4 atque medianibus 2 vel 3. Chloroplastus furcoideus.

\section{Holotype: Figure 4.}

Collection locality: $13 \mathrm{~km}$ north of Jenolan Caves, $100 \mathrm{~m}$ south of Black Range road, $33^{\circ} 45^{\prime} 30^{\prime \prime} \mathrm{S}, 150^{\circ} 02^{\prime} 30^{\prime \prime E}, 1000 \mathrm{~m}$ asl. Oligotrophic pool $10 \times 12 \mathrm{~m}$ and $30 \mathrm{~cm}$ deep, fed by creek, within swampy area surrounded by pine trees, pH 7.6, 3 Oct 1994.

Material containing this taxon has been deposited at NSW.

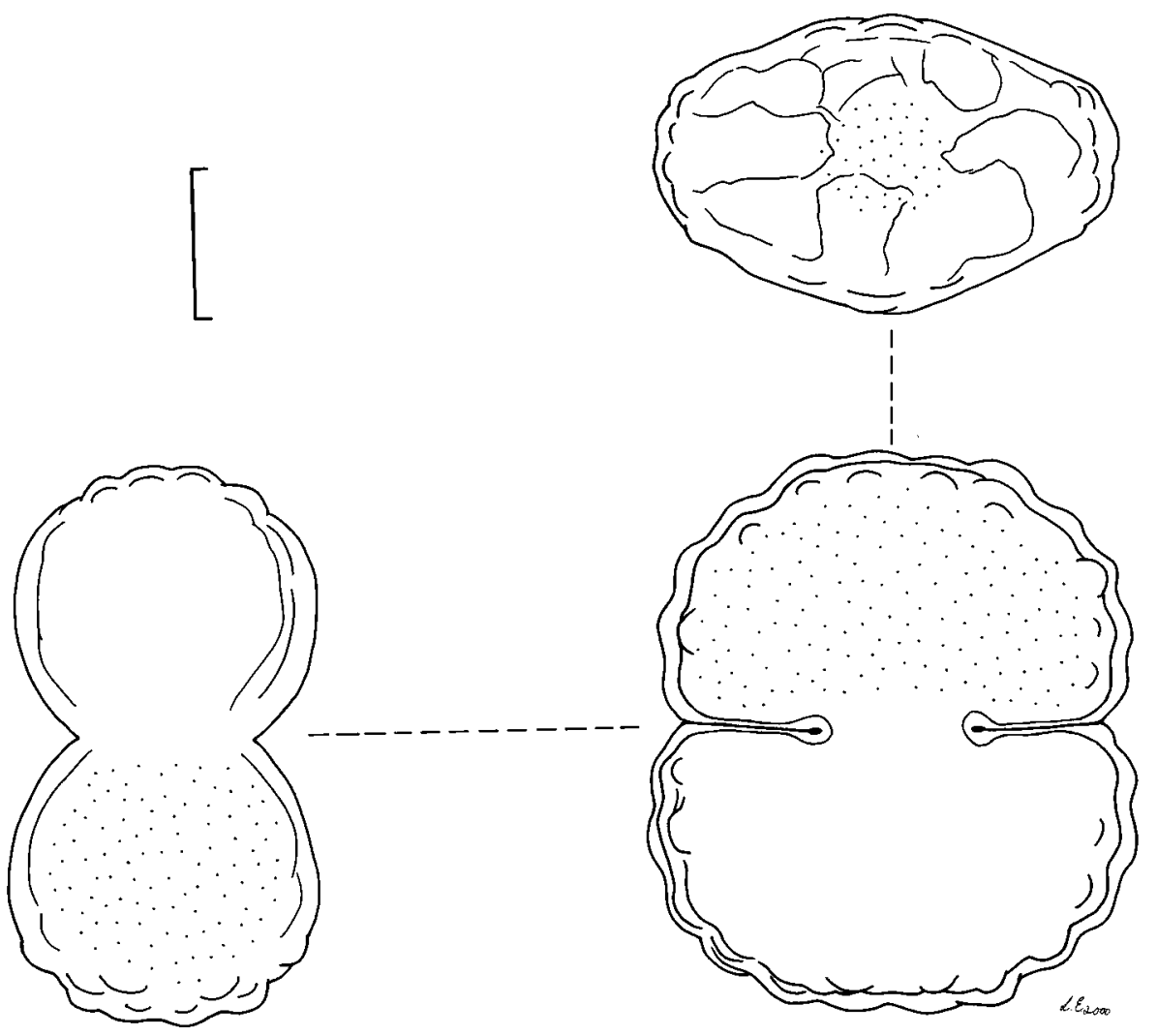

Fig. 4. Holotype of Cosmarium williamsonii M. Dingley. Scale bar $=10 \mu \mathrm{m}$. 
Cells of medium size, sinus deep, linear; semicells semicircular, the sides rounded with four or five undulations and the apex with two faintly discernable undulations, a single row of intramarginal crenae following the same pattern as the marginal ones, the rest of the cell wall finely punctate. Marginal undulations becoming larger towards the apex. Side view semicells sub circular showing apical crenae and apical intramarginal crenae with the rest of the cell wall finely punctate. End view broadly elliptic with four marginal crenae on the ends and two or three in the mid region. Chloroplast furcoid.

Length 36.2-38.1 $\mu \mathrm{m}$, Breadth 33.0-33.7 $\mu \mathrm{m}$, Isthmus 8.5-10.7 $\mu \mathrm{m}$, Thickness 20.0-21.4 $\mu \mathrm{m}$. L.:Br. 1.09-1.13.

The epithet honours David Williamson who has given me help and support in the study of desmids.

Notes: This taxon resembles C. gibberulum Lütkem.(1910) but is sufficiently different in having a more flattened apex, more rounded sides and, in end view, without the two intramarginal rows of granules.

XANTHIDIUM Ehrenberg ex Ralfs

Xanthidium sp. (Fig. 6c).

L. $32.0 \mu \mathrm{m}$, Br. ssp. at apex $27.0 \mu \mathrm{m}$, at basal angle $35.0 \mu \mathrm{m}$, Br. csp. $54.0 \mu \mathrm{m}$, Isth. $11.0 \mu \mathrm{m}$. all measurements were taken from a photograph.

Only one specimen was seen and then only recorded as a photograph. Complete details are not available to describe this as a new species. A thorough check of the Fritsch algal collection on microfiche and subsequent literature has failed to find such a distinctive taxon. The sample site has been revisited several times in order to find more of this taxon but with no success.

Locality: Site 2.

Xanthidium subhastiferum West

West \& West 1912, p. 56, pl. 106 fig. 6.

L. $39.3 \mu \mathrm{m}$, Br. csp. $64.6 \mu \mathrm{m}$, Br. ssp. $40.7 \mu \mathrm{m}$, Isth. $9.8 \mu \mathrm{m}$. (Fig. 7d).

Cells had deeply constricted sinuses which were acute-angled and open. The semicells were elliptic, had a slightly convex apex and were furnished with two simple divergent spines on the lateral angles. The cell walls were punctate becoming coarser towards the centre of each semicell.

Locality: Site 15.

Distribution: North America, United Kingdom, Europe, Faeroes; a new record for Australia.

\section{STAURODESMUS Teiling}

Staurodesmus applanatus $M$. Dingley sp. nov.

Cellulae biradiatae exiguae; semicellulae applanatae in termino, angulis basalibus obtusis; mucro magna sola divergens ex angulis apicalibus; margo terminalis aut stricta aut convexa minime; sinus divergens maxime ex isthmo cylindico longo. Paries vel laevis vel punctulatus; cellula constricta ellipticaque ab extremitate solo mucro visus, subcircula a latere visus. Pyrenoides singula per semicellulam. Zygospora ignota.

Holotype: Figure 5. 


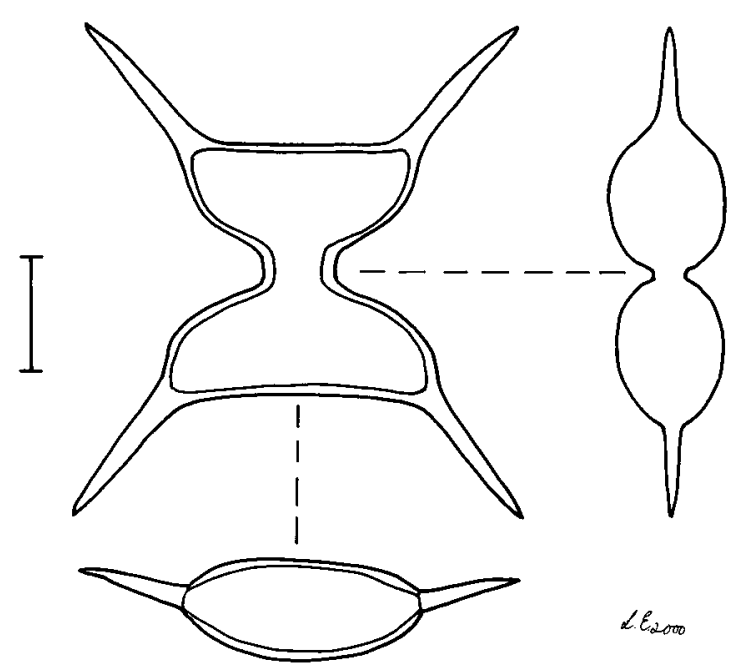

Fig. 5. Holotype of Staurodesmus applanatus M. Dingley. Scale bar $=10 \mu \mathrm{m}$.

Collection locality: Mountain Lagoon, 14 km north east of Bilpin, 3326'40"S, 150 38' 10"E. $450 \mathrm{~m}$ asl. Lagoon, measuring $400 \mathrm{~m} \times 130 \mathrm{~m}$, fed by two small creeks and drained by a third, pH 7.1, 24 Oct 1995.

Material containing this taxon has been deposited at NSW.

Cells biradiate, small; semicells horizontally rectangular. There is a single large divergent spine emanating from each apical corner. Apical margin straight or very slightly convex, basal angles rounded forming a long cylindrical isthmus. Sinus a large U-shape. Cell wall smooth or finely punctate. End view narrowly elliptic with a single spine from narrow ends. Side view sub-circular with a single spine from each end. Single pyrenoid in each semicell.

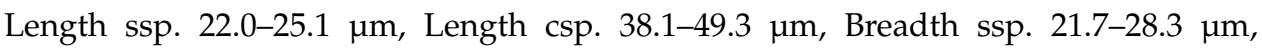

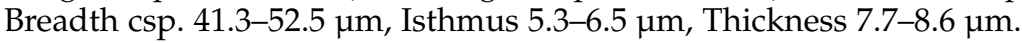

Notes: Staurodesmus applanatus differs from S. extensus (Borge) Teiling with the semicells being horizontally rectangular. It resembles $S$. cuspidatus var. divergens (Nordst.) Teiling except it is biradiate and has much longer spines. It bears a slight resemblance to $S$. validus var. subvalidus (Grönblad) Teiling except that it only has a single pyrenoid in each semicell, it is smaller in size, has a long isthmal tube and a straight apical margin. Vyverman 1991 (Pl. 114, fig. 3) figures S. bulnheimii var. huitfeldtii (Ström) Teiling which is a similar looking biradiate cell but which differs in having longer semicells and a shorter isthmus.

Staurodesmus brevispinus (Bréb.) Croasdale var. brevispinus f. minimus Lütkem.

Croasdale 1962, p. 32, pl. 6, fig. 108.

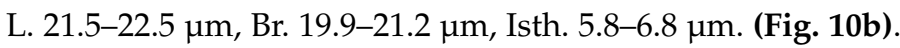

The cells differ from the type variety in being somewhat smaller with some cells showing a finely punctate cell wall. 
Locality: Site 25.

Distribution: Alaska, Europe; a new record for Australia.

Staurodesmus brevispinus var. altus (West) Teiling

Teiling 1967, p. 580, pl. 22, fig. 6.

L. $43.9 \mu \mathrm{m}$, Br. $41.4 \mu \mathrm{m}$, Isth. $16.8 \mu \mathrm{m}$. (Fig. 10e).

The type variety has been previously recorded from Victoria as Staurastrum brevispina by Hardy (1905 \& 1906) and Gibbons (1874) (as Staurastrum brevispinum), both of whom did not illustrate or give measurements. Staurodesmus brevispina var. altus (West) Teiling differs from the typical in having a strongly convex apical part of the semicell and is smaller.

Locality: Site 16.

Distribution: Scotland, Ireland; a new varietal record for Australia.

Staurodesmus convergens (Ehrenb.) Teiling var. convergens

Croasdale et al. 1994, p. 42, pl. 75, figs 1-8.

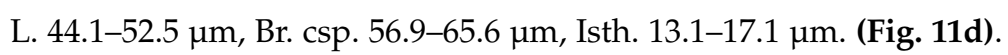

These individuals are slightly larger than those recorded from New Zealand (Croasdale et al. 1994) but not enough to warrant the designation forma major. Cell walls are finely punctate. This taxon differs from S. gibberulus (Joshua) Teiling in having a narrower elliptical cell in end view whereas $S$. gibberulus has an almost spherical appearance.

Locality: Site 13.

Distribution: Previously recorded from Queensland (Grimes 1988); a new record for New South Wales.

Staurodesmus convergens var. ralfsii Teiling

Croasdale et al. 1994, p. 42, pl. 75, figs 13-14.

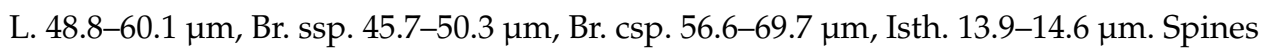
4.8-11.1 $\mu \mathrm{m}$ long. (Fig. 11f).

Individuals of this taxon were very common in the sample. This variety differs from the typical by having a straight apex and this was true for most cells in the sample. However, a few did have a slightly convex apex. Many were surrounded by mucilage layer. It is similar to Arthrodesmus convergens var. curtus W.B. Turner (Scott \& Prescott 1961, pl. 34, figs 5 \& 6).

Locality: Site 13.

Distribution: Previously recorded from the Northern Territory by Thomasson (1986) who listed S. convergens var. ralfsii f. curtus W.B. Turner but did not illustrate it; a new record for New South Wales.

Staurodesmus dickiei (Ralfs) S. Lill. var. maximus (West) Thomasson

Ling \& Tyler 1986, p. 52, pl. 26, fig. 2.

L. $59.7 \mu \mathrm{m}$, Br. ssp. $61.1 \mu \mathrm{m}$, Br. csp. $72.0 \mu \mathrm{m}$, Isth. $14.3 \mu \mathrm{m}$. (Fig. 11e). 
Cell measurements are somewhat larger in this sample and the spines vary in length from small mucros to structures up to $6.5 \mu \mathrm{m}$ in length. Facies 3 , cell wall smooth but sometimes punctate. This variety is larger than the typical. Ling and Tyler 1986, pl. 26 fig. 2 show it more circular in outline

Locality: Site 13.

Distribution: Previously recorded from the Northern Territory and Queensland (Grimes 1988, Ling \& Tyler 1986, Thomasson 1986); a new record for New South Wales.

Staurodesmus mamillatus (Nordst.) Teiling

Croasdale et al. 1994, p. 52, pl. 67, figs 1-6.

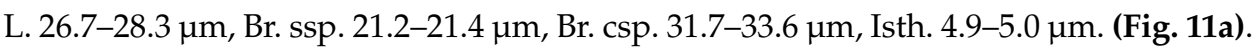

Cells had a narrow and elongated isthmus. Spines moderate in length and divergent.

Locality: Site 13.

Distribution: Previously recorded from the Northern Territory and Tasmania (Croome \& Tyler 1986; Ling \& Tyler 1986 as S. mamillatus forma; Thomasson 1986); a new record for New South Wales.

Staurodesmus mucronatus (Ralfs) Croasdale var. mucronatus

Croasdale et al. 1994, p. 53, pl. 73, figs 1-4.

L. $19.2 \mu \mathrm{m}$, Br. ssp. $18.6 \mu \mathrm{m}$, Br. csp. $20.8 \mu \mathrm{m}$, Isth. $6.7 \mu \mathrm{m}$. Spines ca. $1.1 \mu \mathrm{m}$ long. (Fig. 10f).

In face view the semicells were narrowly oval with the sides tipped with a short spine. Cells had a narrow isthmus and an open sinus. This taxon agrees with Croasdale et al 1994, (p. 53, pl. 73 fig. 2) who state that its distribution is widespread in New Zealand.

Locality: Site 23.

Distribution: This taxon has been recorded from Kangaroo Island off South Australia as Staurastrum mucronatum Ralfs by Prescott and Scott (1952) and from Victoria by Hardy (1906) and with varieties of Staurodesmus mucronatus by Croome and Tyler (1986) and Thomasson (1986); a new record for New South Wales.

STAURASTRUM Meyen ex Ralfs

Staurastrum bibrachiatum Reinsch emend. Grönblad et Scott

Croasdale et al. 1994, p. 86, pl. 103, figs 1-14.

L. $11.9 \mu \mathrm{m}$, Br. cpr. $36.2 \mu \mathrm{m}$, Isth. $5.2 \mu \mathrm{m}$. (Fig. 7c).

Most cells in this sample varied little in morphology, conforming to Type I which is the normal bibrachiatum-like cells as depicted in Croasdale et al. (1994).

Locality: Site $2 b$.

Distribution: S. bibrachiatum var. cymatium West et G.S. West was recorded from Victoria (West 1909); a new record for New South Wales.

Staurastrum coarctatum Bréb. var. solitarium Flint

Croasdale et al. 1994, p. 90, pl. 145, fig. 4.

L. $23.2 \mu \mathrm{m}$, Br. $24.0 \mu \mathrm{m}$, Isth. $7.4 \mu \mathrm{m}$. (Fig. 10g).

These individuals resemble those described by Croasdale et al. (1994, p. 90 Pl. 145, fig. 4) however, they appeared slightly broader and hence more narrowly transversely 
oblong. In end view there were about ten very slight marginal undulations on each of the short processes.

Locality: Site 23.

Distribution: Previously recorded only from New Zealand; a new record for Australia.

Staurastrum ensiferum W.B. Turner forma

Ling \& Tyler 1986, p. 40, pl. 39, figs 23-26.

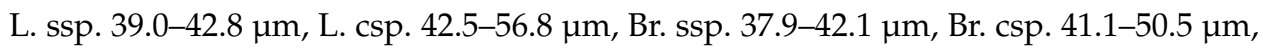
Isth. 13.7-15.3 $\mu \mathrm{m}$. (Fig. 10d).

This taxon is similar to that in Ling \& Tyler (1986). The figure in McLeod (1975 p. 247 pl. 19 fig. 4) shows cells that are larger. However both of the above references show different apical views to those in this sample. Hirano (1959, p. 313, Pl. XL fig. 19) shows it in end view having concave sides. Jao (1949) shows S. ensiferum forma which looks similar in end view to these plants.

Locality: Site 1.

Distribution: Previously recorded from the Northern Territory and Queensland (Ling \& Tyler 1986, McLeod 1975, Thomasson 1986); a new record for New South Wales.

Staurastrum gutwinskii (C. Bernard) f. reductum Scott et Croasdale

Croasdale \& Scott 1976, p. 546, pl. 16, fig. 2.

L. $32.1 \mu \mathrm{m}$, Br. ssp. $32.6 \mu \mathrm{m}$, Br. csp. $54.3 \mu \mathrm{m}$, Isth. $14.8 \mu \mathrm{m}$. (Fig. 10c).

This taxon is of uncertain rank. Prescott et al. (1982, pl. 343, fig. 13) show a similar taxon as S. magnifurcatum Scott \& Grönblad. Another individual is illustrated in Grönblad et al. (1958, fig. 317) as S. forficulatum P. Lundell. var. minus (Fritsch et Rich) Grönblad et Scott. Although it has synonymy with S. furcatum Ehrenb. var. minor Fritsch \& Rich. Grönblad et al. (1958) do say that they 'willingly admit that its systematical position is somewhat dubious'. Croasdale \& Scott 1976 (p. 546 pl. 16 fig. 2) figure S. gutwinskii C. Bernard f. reductum Scott et Croasdale to which the present author assigns this taxon.

Locality: Site 16.

Distribution: Previously recorded from the Northern Territory by Croasdale \& Scott 1976; a new record for New South Wales.

Staurastrum pseudotetracerum (Nordst.) West et G.S. West

Croasdale et al. 1994, p. 127, pl. 101, figs 8-13.

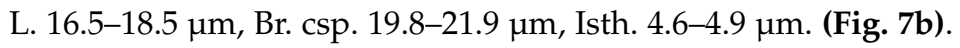

Cells were slightly smaller than those in the published records but not enough to warrant the designation $\mathrm{f}$. minor.

Locality: Site $2 b$.

Distribution: Previously recorded from the Northern Territory (Ling \& Tyler 1986, Thomasson 1986); a new record for New South Wales.

Staurastrum simplicius (Scott et Grönblad) Coesel

Coesel 1997, p. 53, pl. 22, figs 4-5.

L. $20.7 \mu \mathrm{m}$, Br. $52.9 \mu \mathrm{m}$, Isth. $4.4 \mu \mathrm{m}$. (Fig. 10a). 
These biradiate cells have long divergent arms tipped with three spines. They differ from the typical in having a lack of spines and verrucae on the body.

Locality: Site 6.

Distribution: United States, Europe; a new record for Australia.

Staurastrum spongiosum Bréb. ex Ralfs forma

Prescott et al. 1982, p. 315, pl. 345, fig. 8.

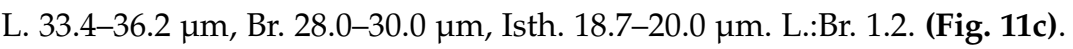

Cells were medium sized with the sinus shallow and wider open than in the typical; in end view cells were triangular with each margin having about four teeth. These algae were smaller than the typical and as such are depicted here as a form. Most were surrounded by a mucilage layer.

Locality: Site $2 b$.

Distribution: North America, Europe, United Kingdom, Asia, Africa, South America, Arctic; a new record for Australia.

Staurastrum striatum (West et G.S. West) Ruzicka

Coesel 1997, p. 54, pl. 3, figs 9-11.

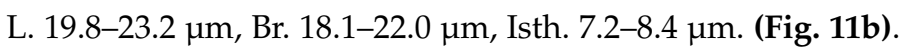

The semicells are more distinctly rhomboid than in the type; granules are smaller and fewer in number. Measurements are slightly smaller than those quoted in the literature.

Locality: Site 2.

Distribution: England, Europe; a new record for Australia.

Staurastrum subradians M.F. Rich forma

Croasdale et al. 1994, p. 140, pl. 105, figs 10-11.

L. $28.3 \mu \mathrm{m}$, Br. csp. $43.3 \mu \mathrm{m}$, Br. ssp. $41.7 \mu \mathrm{m}$, Isth. $8.8 \mu \mathrm{m}$. (Fig. 7a).

This taxon is consistent with that documented in Rich (1935, p. 148, fig. 20) and Croasdale et al. (1994, pl. 105, figs 10-11) who show it as a form. I have also assigned this taxon as a form as details seem to place it between those of Rich (1935) who shows it as a 6-radiate form having, in end view, a central granule surrounded by a ring of other granules, and Croasdale et al. (1994) who show it as a 5-radiate form with a stronger ornament, particularly in end view; concave sides bearing 2 intramarginal verrucae with the central area smooth. The taxon in question here is 6-radiate and has a stronger ornament than Rich's. It is similar to that in Croasdale et al.(1994) in general morphology and has a ring of small granules in end view but without a central granule.

Locality: Site 13.

Distribution: Africa, New Zealand; a new record for Australia.

TEILINGIA Bourrelly

Teilingia excavata (Ralfs ex Ralfs) Bourr. et Compère

Croasdale et al. 1994, p. 168, pl. 130, figs 1-4.

L. $10.0 \mu \mathrm{m}$, Br. $7.9 \mu \mathrm{m}$, Isth $5.2 \mu \mathrm{m}$. L.:Br. 1.2. (Fig. 6e). 
Apex flattened and in face view two granules were visible near the outer margin. Cell wall smooth. Cells were seen in short filaments containing 7-13 cells.

Locality: Site 13.

Distribution: Previously recorded from the Northern Territory (Thomasson 1986); new record for New South Wales.

Teilingia granulata (Roy et Bisset) Bourr. ex Compère

Croasdale et al. 1994, p. 1698, pl. 130, figs 5-8.

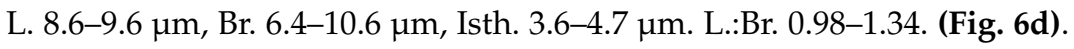

Apices were flat showing 2 small granules on each side. Lateral margins contained three tiny granules and two intramarginal granules. Filaments were up to 18 cells long.

Locality: Site 13.

Distribution: Previously recorded from Northern Territory (Thomasson 1986); a new record for New South Wales.

SPONDYLOSIUM Brébisson ex Ralfs

Spondylosium pygmaeum (Cooke) West var. monile (W.B. Turner)

West et al. 1923, p. 221, pl. 160, figs 20, 21.

L. $7.0 \mu \mathrm{m}$, Br. $5.0 \mu \mathrm{m}$, Isth. $3.8 \mu \mathrm{m}$, L.:Br. 1.4. (Fig. 6f).

A single filament was observed consisting of 13 Cosmarium-type cells joined at their apices. Each semicell had 1 or 2 almost indiscernible granules but this was not consistent among cells. Although the author has not been able to examine S. pygmaeum (Cooke) West it does seem to agree with the description in West et al. (1923, p. 221, pl. 160 , figs 20,21) being longer, more broadly oval and semiglobular.

Locality: Site 13.

Distribution: U.S.A. United Kingdom, Europe; a new record for Australia.

HYALOTHECA Ehrenberg ex Ralfs

Hyalotheca javanica (Gutw.) Coesel

Coesel 2000, p. 379, figs 39-40.

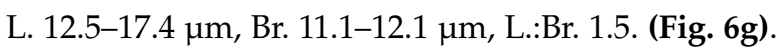

Coesel (2000) proposed H. javanica (from H. indica W.B. Turner var. javanica Gutw.) on the basis of the $H$. indica being a doubtful species and that $H$. javanica at species level has a much wider and shallower (not seldom even untraceable) sinus, and less rounded angles.

Locality: Site 11.

Distribution: Previously recorded from the Northern Territory by Thomasson (1986) as $H$. indica var. javanica Gutw; a new record for New South Wales. 

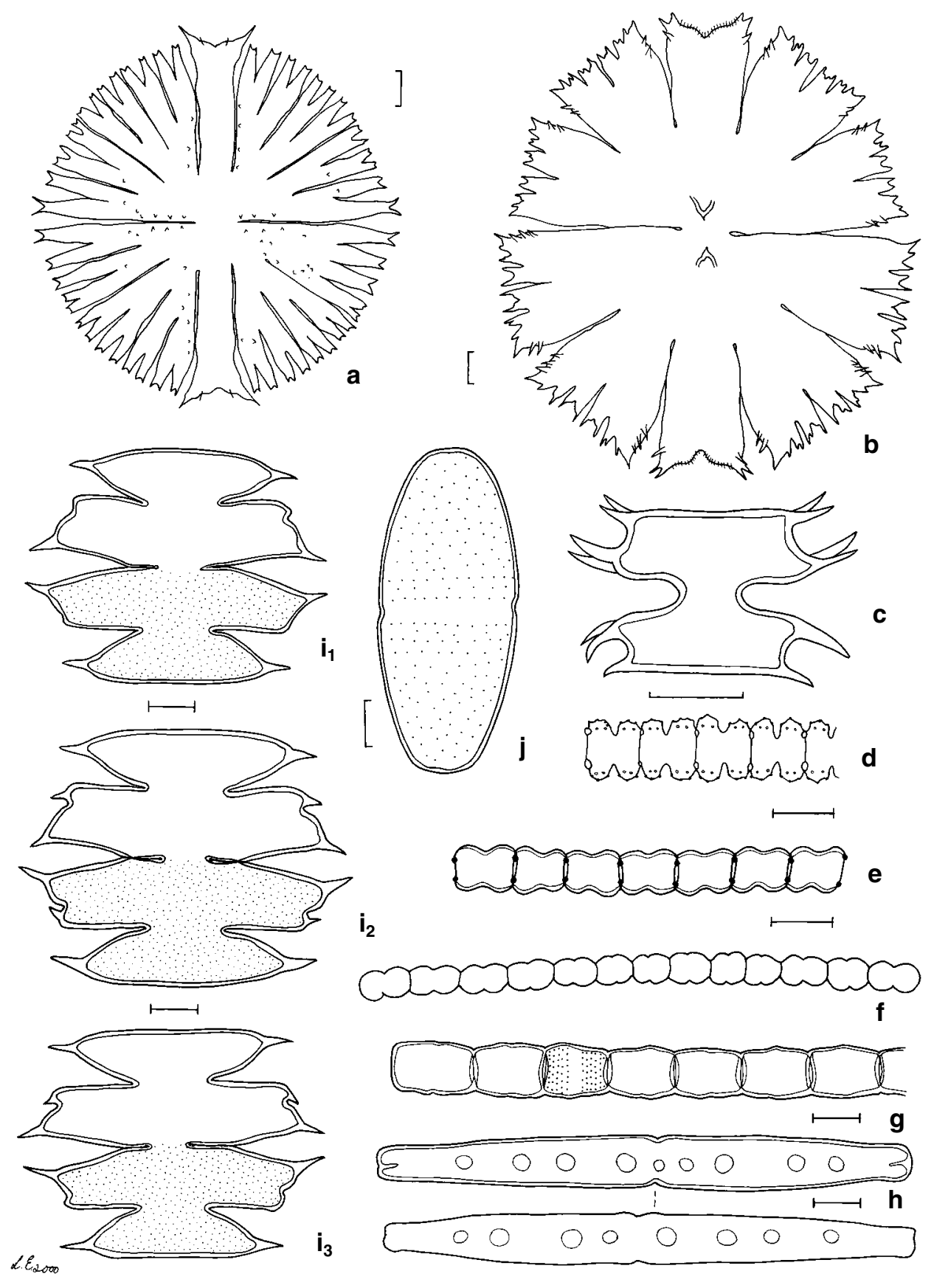

Fig. 6. a, Micrasterias rotata var. rotata f. evoluta; b, Micrasterias sp.; c, Xanthidium sp.; d, Teilingia granulata; e, Teilingia excavata; f, Spondylosium pygmaeum var. monile; $\mathbf{g}$, Hyalotheca javanica; $\mathbf{h}$, Tetmemorus brebissonii var. tenuissimus; $\mathbf{i}$, Micrasterias zeylanica three different forms; $\mathbf{j}$, Actinotaenium cucurbitinum var. subpolymorphum. Scale bars: $\mathrm{a}-\mathrm{c}=20 \mu \mathrm{m} ; \mathrm{d}-\mathrm{j}=10 \mu \mathrm{m}$. 

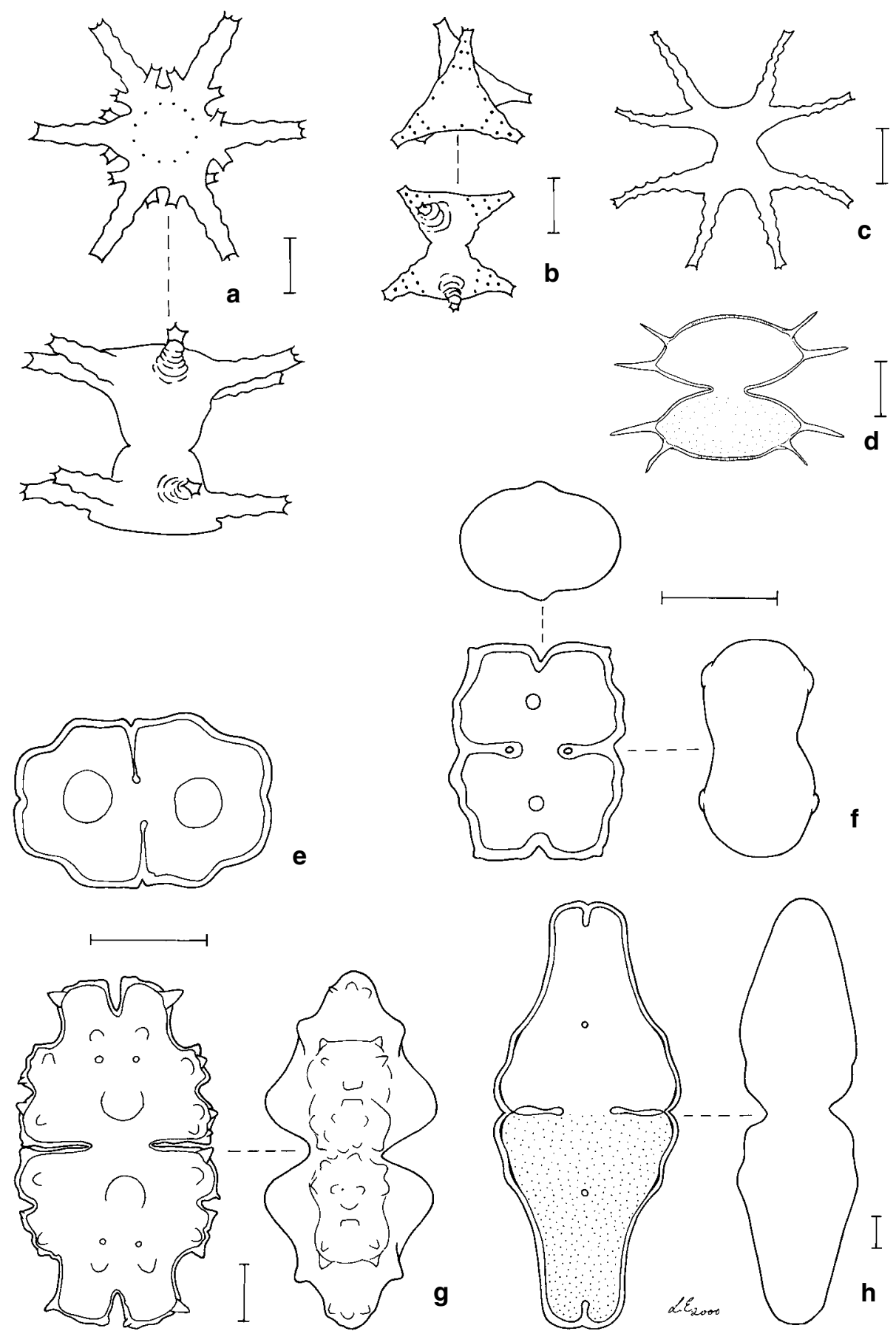

Fig. 7. a, Staurastrum subradians; b, Staurastrum pseudotetracerum; c, Staurastrum bibrachiatum; d, Xanthidium subhastiferum; e, Euastrum insulare var. silesiacum; $\mathbf{f}$, Euastrum insulare var. insulare; $\mathbf{g}$, Euastrum praemorsum; h, Euastrum ansatum var. dideltiforme. Scale bars: all $=10 \mu \mathrm{m}$. 


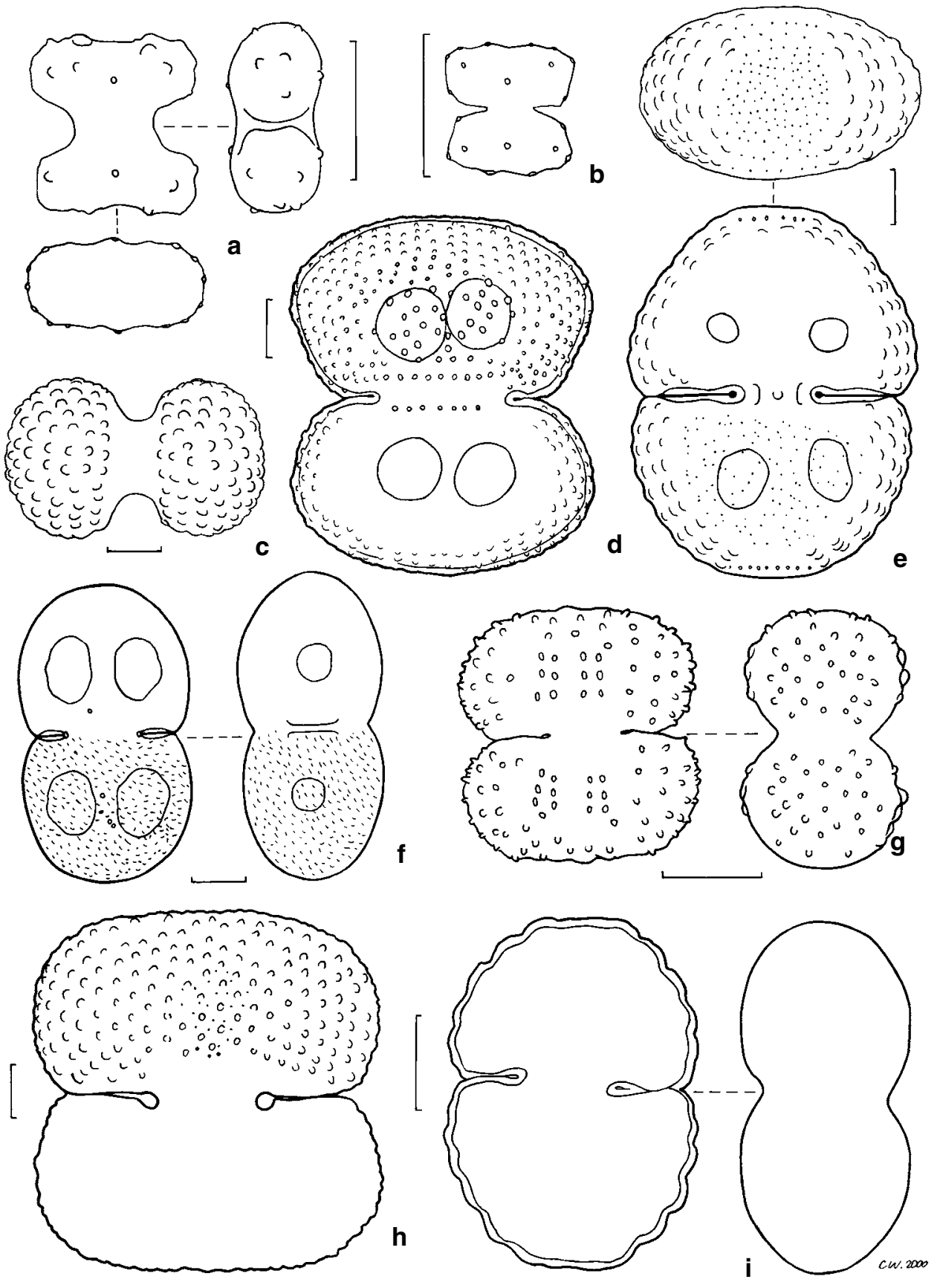

Fig. 8. a, Cosmarium regnesii var. montanum; $\mathbf{b}$, Cosmarium cymatonotophorum; $\mathbf{c}$, Cosmarium isthmium; d, Cosmarium biretum; e, Cosmarium obtusatum; $\mathbf{f}$, Cosmarium quadratum var. willei; $\mathbf{g}$, Cosmarium quadriverrucosum var. supraornatum; $\mathbf{h}$, Cosmarium quadrum var. sublatum; $\mathbf{i}$, Cosmarium subundulatum. Scale bars: all $=10 \mu \mathrm{m}$. 

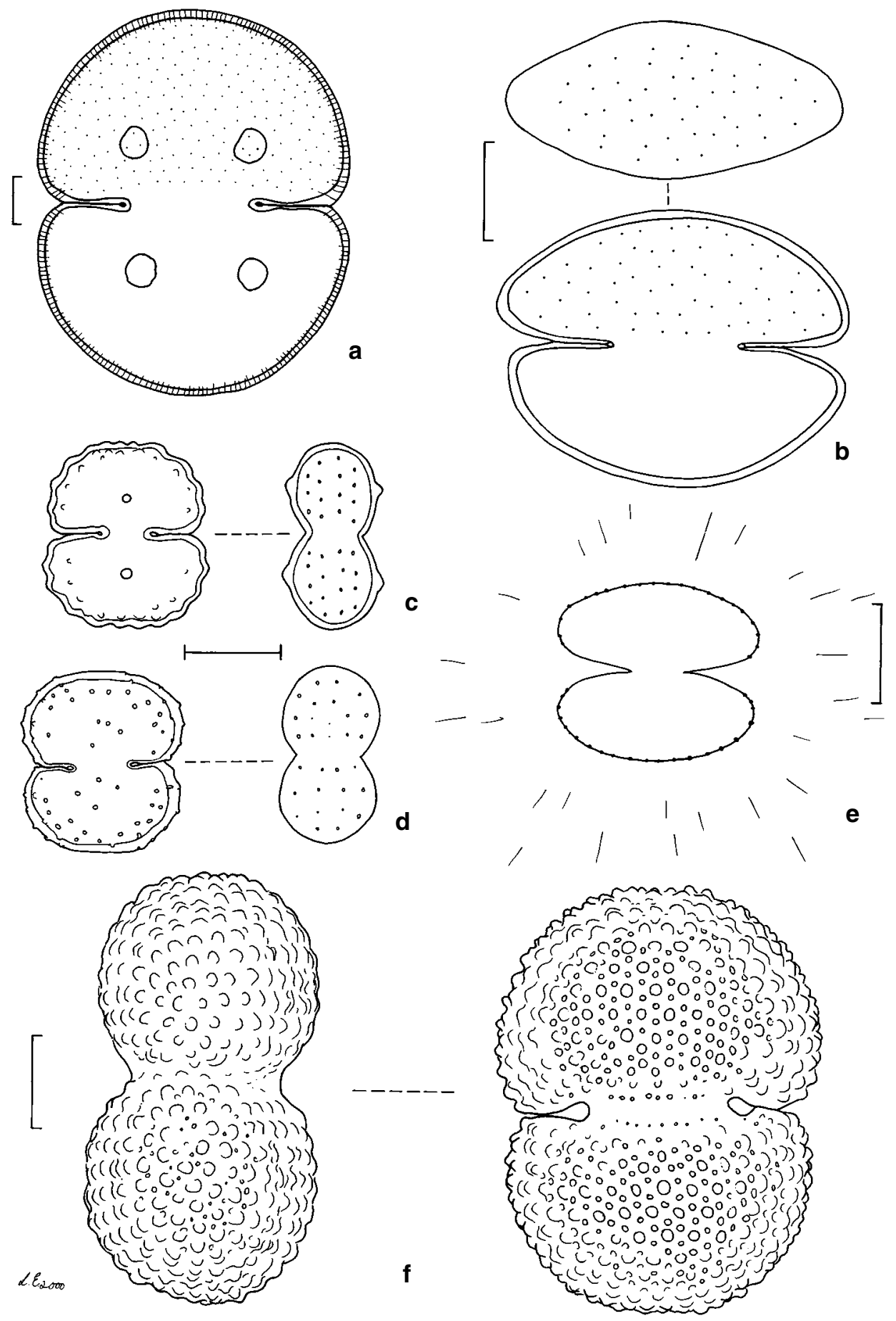

Fig. 9. a, Cosmarium pachydermum; b, Cosmarium dorsitruncatum; c, Cosmarium blyttii var. blyttii; d, Cosmarium punctulatum var. minor; e, Cosmarium depressum var. depressum f. minutum; f, Cosmarium margaritatum. Scale bars: a-e $=10 \mu \mathrm{m} ; \mathrm{f}=20 \mu \mathrm{m}$. 

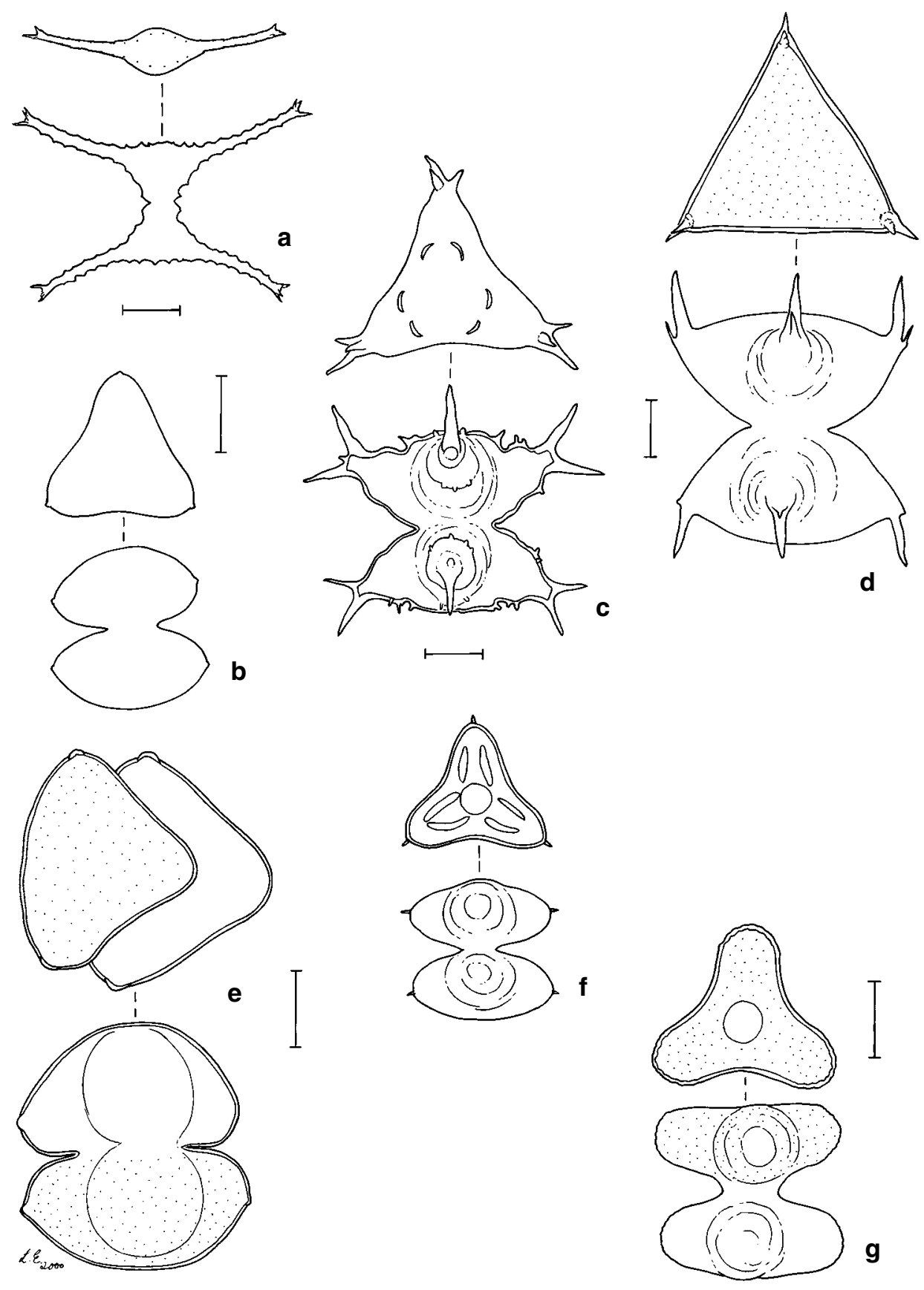

Fig. 10. a, Staurastrum simplicius; b, Staurodesmus brevispinus var. brevispinus f. minimus; c, Staurastrum gutwinskii f. reductum; d, Staurastrum ensiferum; e, Staurodesmus brevispinus var. altus; f, Staurodesmus mucronatus var. mucronatus; $\mathbf{g}$, Staurastrum coarctatum var. solitarium. Scale bars: all $=10 \mu \mathrm{m}$. 


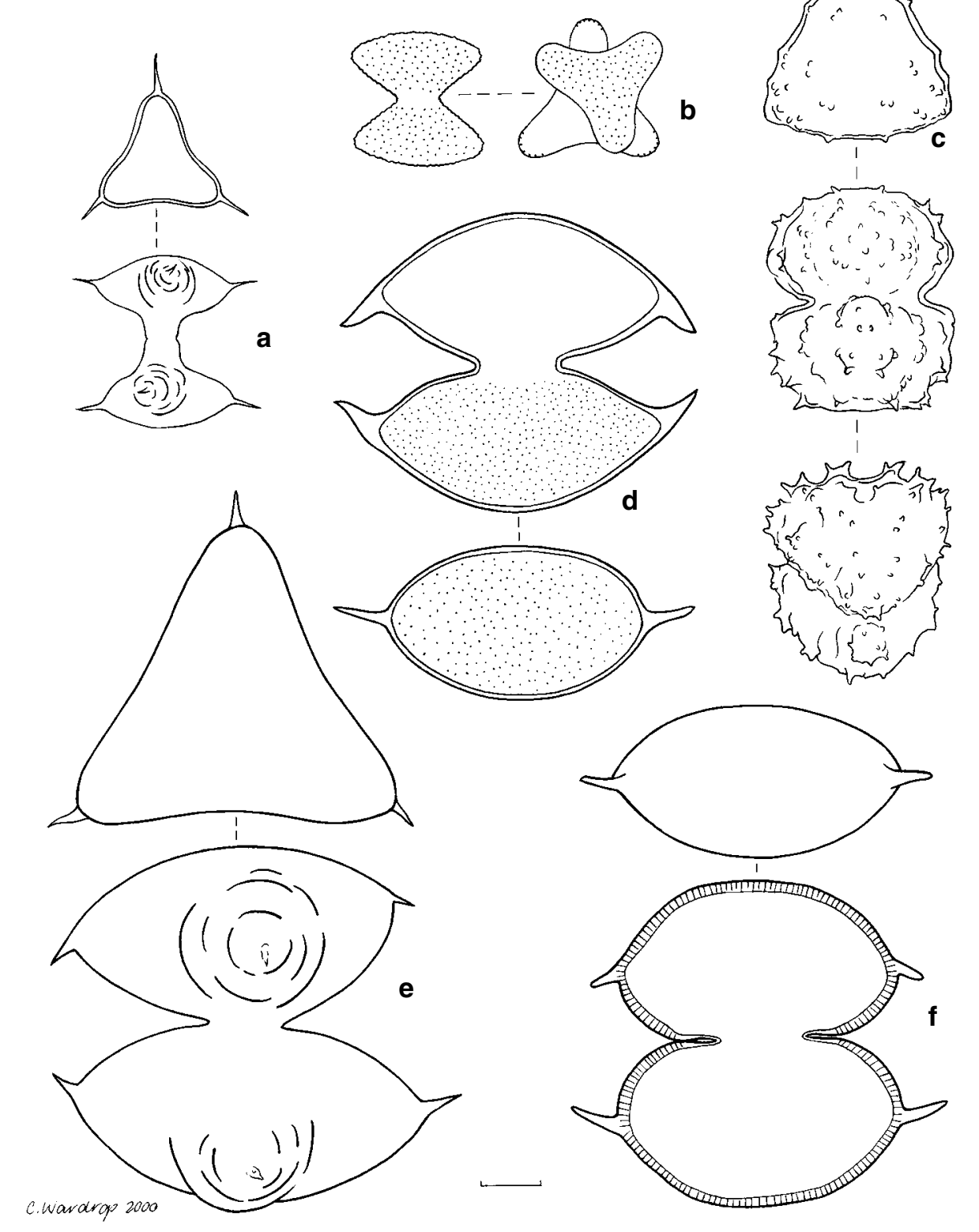

Fig. 11. a, Staurodesmus mamillatus; b, Staurastrum striatum; c, Staurastrum spongiosum forma; d, Staurodesmus convergens var. convergens; e, Staurodesmus dickiei var. maximus; $\mathbf{f}$, Staurodesmus convergens var. ralfsii. Scale bar $=10 \mu \mathrm{m}$. 


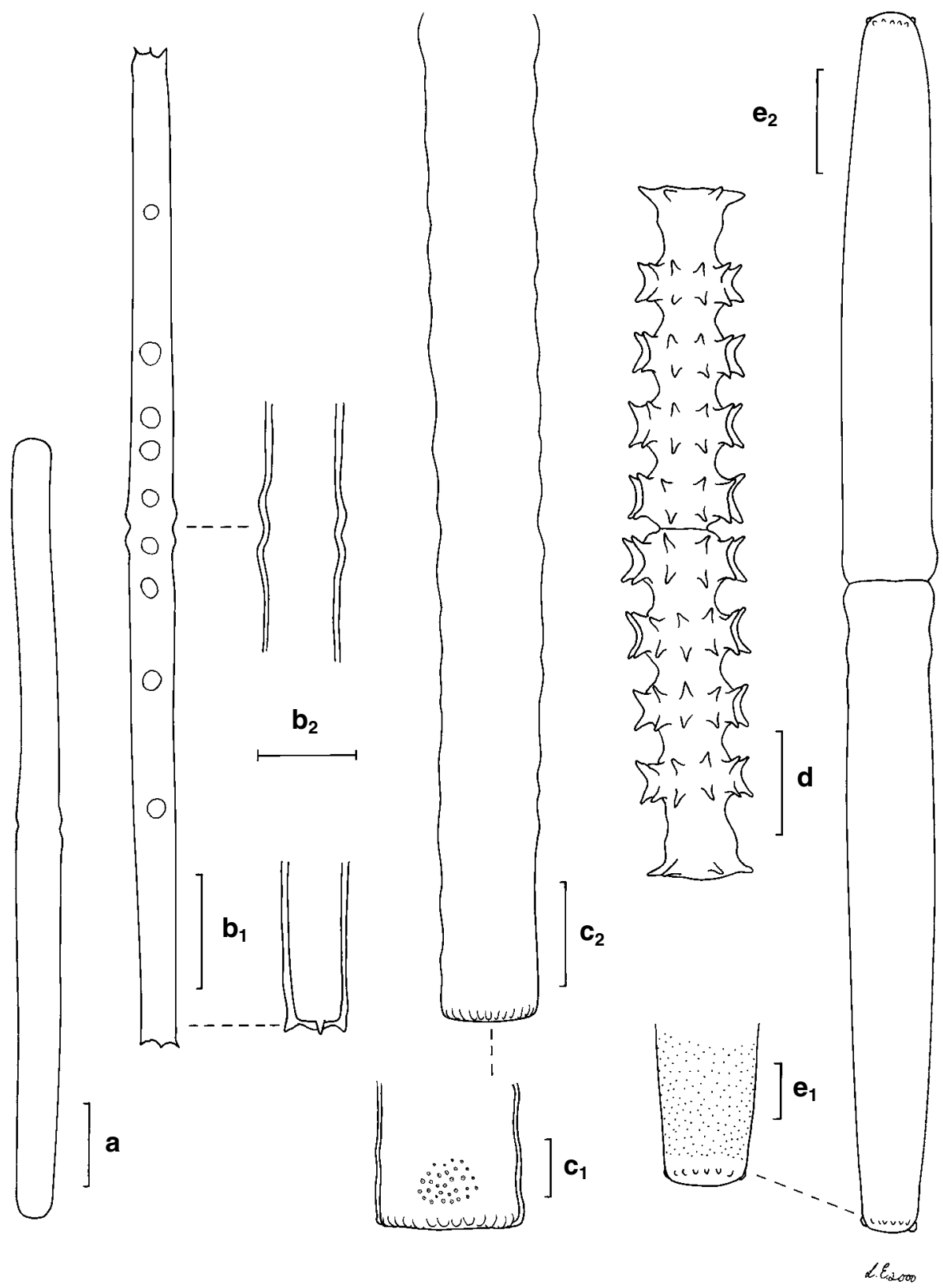

Fig. 12. a, Haplotaenium minutum var. cylindricum; b, Pleurotaenium sceptrum; c, Pleurotaenium eugeneum var. undulatum; d, Pleurotaenium kayei; e, Pleurotaenium truncatum var. farquharsonii. Scale bars: $a, b_{1}, c_{1}, e_{1}=20 \mu \mathrm{m} ; b_{1}=20 \mu \mathrm{m}, b_{2}=10 \mu \mathrm{m} ; c_{2}, d, e_{2}=50 \mu \mathrm{m}$. 

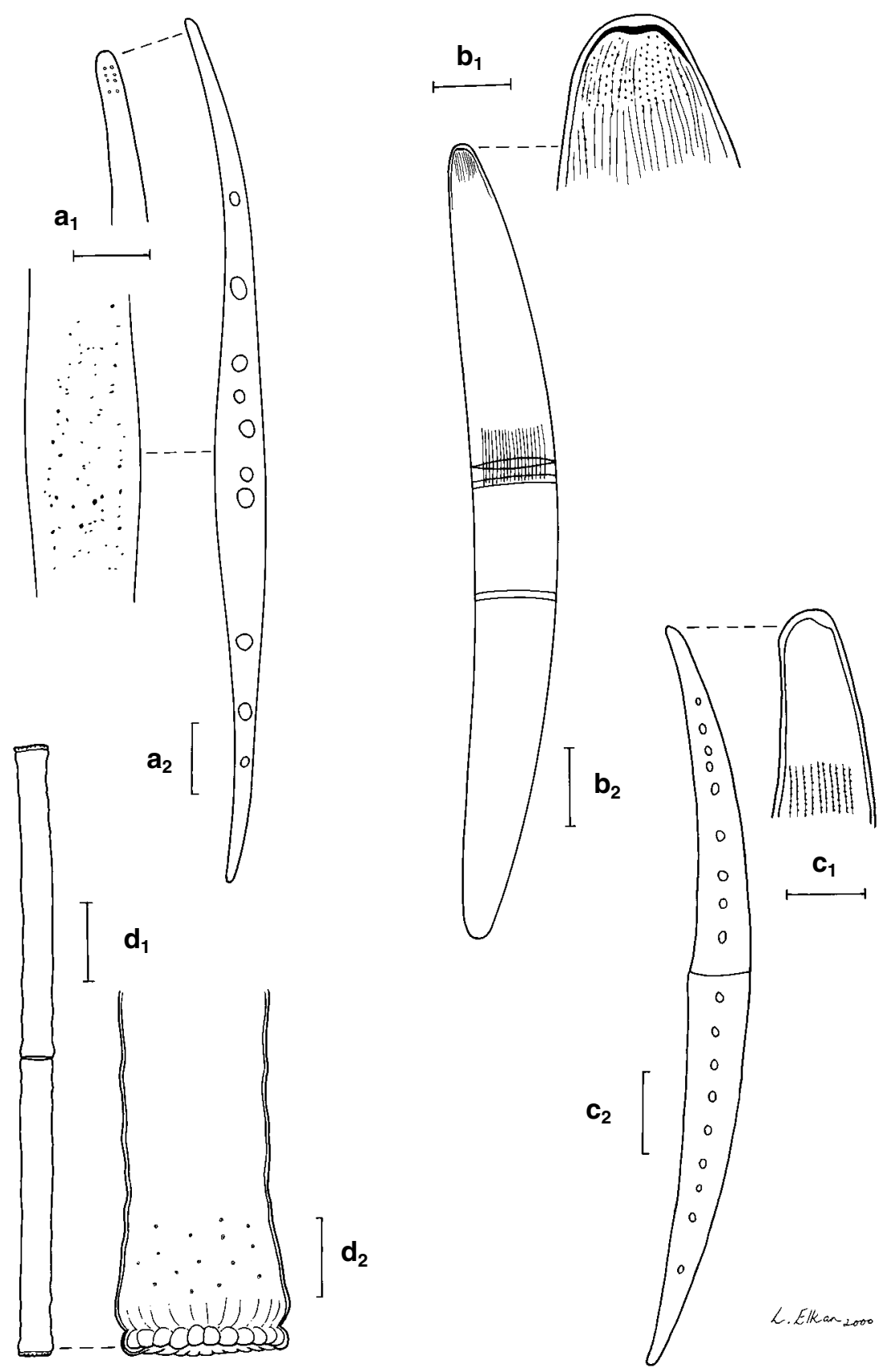

Fig. 13. a, Closterium strigosum var. elegans; b, Closterium didymotocum; c, Closterium ralfsii var. hybridum; d, Pleurotaenium subcoronulatum var. subcoronulatum. Scale bars: $\mathrm{a}_{1}, \mathrm{~b}_{1}, \mathrm{c}_{1}=10 \mu \mathrm{m} ; \mathrm{a}_{2}, \mathrm{~d}_{2}$ $=20 \mu \mathrm{m} ; \mathrm{b}_{2}, \mathrm{c}_{2}=50 \mu \mathrm{m} ; \mathrm{d}_{1}=100 \mu \mathrm{m}$. 

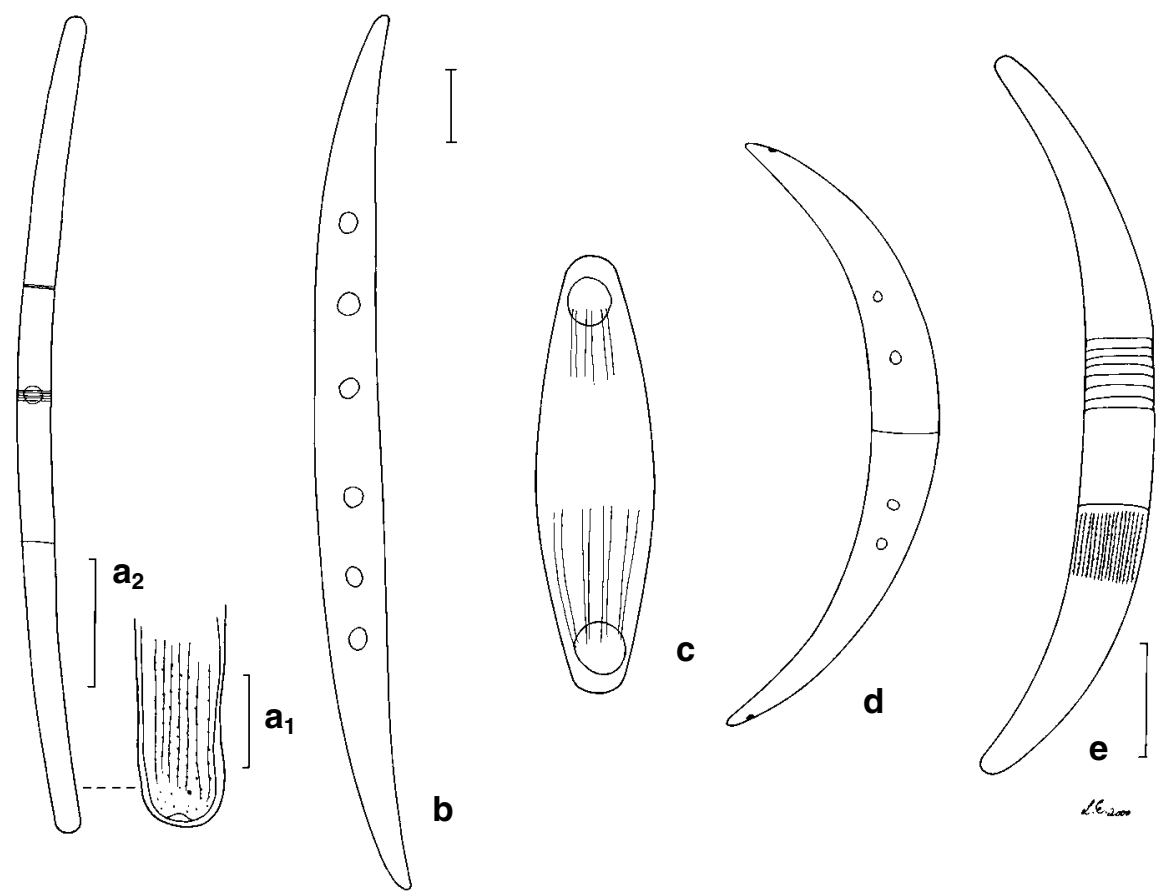

Fig. 14. a, Closterium subscoticum; b, Closterium strigosum var. strigosum; c, Closterium navicula; d, Closterium venus var. westii; $\mathbf{e}$, Closterium intermedium var. intermedium. Scale bars: $\mathrm{a}_{1}, \mathrm{~b}_{1},=10 \mu \mathrm{m}$; $\mathrm{a}_{2}=50 \mu \mathrm{m} ; \mathrm{c}-\mathrm{e}=20 \mu \mathrm{m}$.

\section{Discussion}

This paper presents five proposed new species, 58 new records for New South Wales of which 27 are newly recorded in Australia and two taxa (Xanthidium sp. and Micrasterias sp.) that could prove to be new to science if further collections containing these algae can be made in order to ascertain this with certainty. Three sites $(2,11,13)$ out of a total of 25 , between them contained $57 \%$ of the taxa recorded $(10,11$ \& 16 taxa respectively). Three of the five proposed new species were found at site 2, as was the single specimen Xanthidium sp. Two taxa, Closterium navicula (Bréb.) Lütkem. and Closterium strigosum Bréb. var. strigosum, were each found at three sites indicating a more widespread distribution than was previously known; this may prove to be the case for more taxa if and when more collections are examined and recorded.

Tyler (1970) states that 'the known distribution of desmids is none other than the known distribution of desmidiologists and the latter have been scarce in the southern hemisphere'. This is particularly noticeable in this study with such a high number of taxa being recorded for the first time in Australia. Australia is a huge continent and further collecting, examination and recording of desmids must be given a priority in order to build up a more comprehensive knowledge of the species and their localities and habitats. 


\section{Acknowledgments}

The author wishes to thank the Royal Botanic Gardens, Sydney for funding this project through the NSW Biodiversity Strategy, in particular Dr Timothy Entwisle. Thanks are also due to Dr Peter Coesel for reading and making comments on the manuscript, to the anonymous referees for constructive criticisms, to Prof. R. Lenzenweger for help in supplying reference material, to Dr Peter Wilson and Dr Stephen Skinner, Royal Botanic Gardens Sydney for writing the Latin diagnoses, Lesley Elkan and Catherine Wardrop for preparing the plates and David Williamson for allowing me to reproduce his drawings on Fig. 11c.

\section{References}

Anon. (1946) Exhibits and Excursions [to Alexandra Gardens and Domain]. Proc. Microscop. Soc. Victoria 6(7): 3.

Bailey, F.M. (1898) Contributions to the Queensland Flora, Queensland Freshwater Algae. Bot. Bull. Dept. Agric., Queensland No. 15.

Bailey, F.M. (1913) Algae, in F.M. Bailey, Comprehensive Catalogue of Queensland Plants both Indigenous and Naturalised. (Queensland Department of Agriculture: Brisbane) pp. 678-682: 792-832: 852.

Borge, O. (1896) Australische Süsswasserchlorophyceen. Bih. Kongl. Svenska Vet. Aakad. Handl. Afd. 22(III, 9):1-32, Pls. 1-4.

Bourrelly, P. (1964) Une nouvelle coupure générique dans la famille des Desmidiées: le genre Teilingia. Rev. Algol. II, 7(2): 187-191.

Cheng, D.M.N. \& Tyler, P.A. (1973) Lakes Sorrell and Crescent - a Tasmanian paradox. Int. Rev. Gesamten Hydrobiol. 58: 307-342.

Coesel, P.F.M. (1997) De Desmidiaceeën Van Nederland. Deel 6 Fam. Desmidiaceae (4). Wetenschappelijke Mededeling KNNV nr. 220.

Coesel, P.F.M. (2000). Desmids (Chlorophyta, Desmidiaceae) from Thale Noi (Thailand). Nord. J. Bot. 20 (3): 369-383.

Croasdale, H. (1962) Freshwater Algae of Alaska III. Desmids from the Cape Thompson Area. Trans. Amer. Micro. Soc. 81(1): 12-42.

Croasdale, H, \& Flint, E.A. (1986) Flora of New Zealand Desmids. Volume I. (V.R. Ward, Government Printer: Wellington, New Zealand).

Croasdale, H, \& Flint, E.A. (1988) Flora of New Zealand Desmids. Volume II. (Botany Division, D.S.I.R.: New Zealand).

Croasdale, H, Flint, E.A. \& Racine, M.M. (1994) Flora of New Zealand. Freshwater Algae, Chlorophyta, Desmids with ecological comments on their habitats Vol. III. (Manaaki Whenua Press: Lincoln, New Zealand).

Croasdale, H. \& Scott, A.M. (1976) New or otherwise interesting desmids from Northern Australia. Nova Hedwigia 27: 501-594.

Croome, R.L. \& Tyler, P.A. (1986) Taxonomy and ecology of the phytoplankton in Lake Fidler and Sulphide Pool, meromictic Tasmanian lakes. Hydrobiologia 140: 135-141.

Darling, R.B. (1982) A Floristic Study of the Algae Inhabiting a Sphagnum Bog at Lake Mountain, Victoria, B.Sc. (Hons.) thesis, Botany Department, University of Melbourne, Melbourne.

Day, S.A., Wickham, R.P., Entwisle, T.J. \& Tyler, P.A. (1995) Bibliographic Checklist of Non-Marine Algae in Australia. (Australian Biological Resources Study: Canberra).

Dingley, M.O. (1995) Desmids (Zygnemaphyceae) from a shallow wheel rut subject to drying. Quekett J. Microscopy 37: 374-378.

Gibbons, S. (1874) Air and water poisoning in Melbourne. Trans. Proc. Roy. Soc. Victoria 10: 180-202.

Grimes, J.A. (1988) The Algae, in G. Scott (ed.), Lake Broadwater. The Natural History of an Inland Lake and its Environs, pp. 105-133. (Darling Downs Institute Press [in association with Lake Broadwater Natural History Association]).

Grönblad, R, Prowse, G.A. \& Scott, A.M. (1958) Sudanese desmids. Acta Botanica Fennica 58: 1-82.

Hardy, A.D. (1905) The fresh-water algae of Victoria, Part II. Victorian Naturalist 22: 31-35: 62-73.

Hardy, A.D. (1906) The fresh-water algae of Victoria, Part III. Victorian Naturalist 23: 18-22: 33-42. 
Hardy, A.D. (1931-1956) Algological Reports by Honorary Algologist. Melbourne and Metropolitan Board of Works. Half Yearly (1931-1942) and Quarterly (1943-1956). [Unpublished; copy at Royal Botanic Gardens, Melbourne].

Harrop, E.D. (1869) Observations of desmidiaceae, with a list of species found in Tasmania. Monthly Notices of Papers and Proc. Roy. Soc. Tasmania (for 1868) 1868: 19-22.

Hirano, M. (1959) Flora Desmidiarum Japonicarum VI. Contr. Biol. Lab. Kyoto Univ. No. 9.

Jao, C.C. (1949) Studies on the freshwater algae of China. XIX. Desmidiaceae from Kwangsi. Bot. Bull. Acad. Sinica 3(2):37-95.

Johnson, L.N. (1895) Some new and rare desmids of the United States - II. Bull. Torr. Bot. Club 22 (7): 289-298.

Kouwets, F.A.C. (1997) Contributions to the knowledge of the French desmid flora 1. New and noteworthy taxa from the Central and Eastern Pyrenees. Arch. Protistenkd. 148: 33-51.

Krieger, W. \& Gerloff, J. (1962) Die Gattung Cosmarium. Lieferung 1. pp. 1-112 (J. Kramer: Weinheim).

Lenzenweger, R. (1989a) Beitrag zur Kenntnis der Zieralgenflora des Egelsees Bei Abtenau (Salzburg, Österreich). Stapfia 22: 45-79.

Lenzenweger, R. (1989b) Zieralgen von Süd-Grönland. Stapfia 22: 81-140.

Ling, H.U. \& Tyler, P.A. (1986) A Limnological Survey of the Alligator Rivers Region. Part II: Freshwater Algae, exclusive of diatoms, Research Report 3. (Australian Government Publishing Service: Canberra).

Lütkemüller, J. (1910). Zur Kenntnis der Desmidiaceen Böhmens, Verh. K. K. Zool. -Bot. Ges. in Wien 60: 488 .

McLeod, J.A. (1975) The Freshwater Algae of Southern Queensland, unpublished PhD thesis, University of Queensland.

Möbius, M. (1892) Australische Süsswasseralgen. Flora. 3: 421-450.

Möbius, M. (1895) Australische Süsswasseralgen II. Abh. Senckenb. Natur. Ges. 18: 309-352.

Näegeli, C. (1849) Gattungen einzelliger Algen physiologisch und systematisch bearbeitet. Neue Denkschr. D. allg. Schweiz. Gesellsch. F.d. Ges. Naturwissensch 10: 1-139.

Nordstedt, C.F.O. (1888) Freshwater algae collected by Dr. S. Berggren in New Zealand and Australia. Kongl. Svenska Vet.-Akad. Handl. 22(8):1-98.

Playfair, G.I. (1907) Some new or less known desmids found in New South Wales. Proc. Linn. Soc. New South Wales 32 (1):160-201.

Playfair, G.I. (1908) Some Sydney desmids. Proc. Linn. Soc. New South Wales 33 (3): 603-628.

Playfair, G.I. (1910) Polymorphism and life-history in the Desmidiaceae. Proc. Linn. Soc. New South Wales 35: 459-495.

Playfair, G.I. (1912) Plankton of the Sydney water supply. Proc. Linn. Soc. New South Wales 37 (3): 512-552.

Playfair, G.I. (1914) Contributions to a knowledge of the biology of the Richmond River. Proc. Linn. Soc. New South Wales 39: 93-151.

Playfair, G.I. (1915) Freshwater algae of the Lismore district with an appendix on the algal fungi and Schizomycetes. Proc. Linn. Soc. New South Wales 40: 310-362.

Playfair, G.I. (1917) Census of New South Wales fresh-water algae, in J.H. Maiden \& E. Betche (eds), A Census of New South Wales Plants, Suppl. 1, pp. 219-262.

Prescott, G.W., Croasdale, H.T. \& Vinyard, W.C. (1975). A Synopsis of North American Desmids. Part II. Desmidiaceae: Placodermae Section I, pp. 1-275.(Univ. Nebraska Press).

Prescott, G.W., Croasdale, H.T. \& Vinyard, W.C. (1977) A Synopsis of North American Desmids. Part II. Desmidiaceae: Placodermae Section 2. pp. 1-413. (Univ. Nebraska Press).

Prescott, G.W., Croasdale, H.T., Vinyard, W.C. \& Bicudo, C. E. de M. (1981) A Synopsis of North American Desmids. Part II. Desmidiaceae: Placodermae Section 3. pp. 1-720. (Univ. Nebraska Press).

Prescott, G.W., Croasdale, H.T., Vinyard, W.C. \& Bicudo, C. E. de M. (1982) A Synopsis of North American Desmids. Part II. Desmidiaceae: Placodermae Section 4. pp. 1-700.(Univ. Nebraska Press).

Prescott, G.W. \& Scott, A.M. (1952) Some South Australian desmids, Trans. Roy. Soc. South Australia 75: 55-69.

Ralfs, J. (1848) The British Desmidieae. XXII (London).

Rich, F. (1935) Contributions to our knowledge of the freshwater algae of Africa. Trans. Roy. Soc. South Africa 23: 107-160.

Ruzicka, J. (1977) Die Desmidiaceen Mitteleuropas. Vol. 1. pp. 1-291 (E. Schweizerbart'sche Verlagsbuchhandlung: Stuttgart). 
Ruzicka, J. (1981) Die Desmidiaceen Mitteleuropas. Vol. 2. pp. 1-736. (E. Schweizerbart'sche Verlagsbuchhandlung: Stuttgart).

Schmidle, W. (1896) Süsswasseralgen aus Australien. Flora, Jena 82: 297-313.

Scott, A.M. (1954) Some new and little-known desmids from North Australia and Indonesia. Rapp. Comm. 8eme Congr. Intern. Bot. 17: 171-173.

Scott, A.M. \& Prescott G.W. (1958), Some freshwater algae from Arnhem Land in the Northern Territory of Australia. Records Amer-Austr. Sci. Exped. Arnhem Land 3: 9-136.

Skinner, S. (1980) New records of Zygnemaphyceae and Oedogoniophyceae (Chlorophyta) from northern New South Wales. Proc. Linn. Soc. New South Wales 104 (4): 245-263.

Skuja, H. (1976) Zur Kenntnis der Algen Neuseeländischer Torfmoore. Nova Acta Reg. Soc. Sci. Upsaliensis, V, 2:7-158.

Sormus, L. (1996) Desmidiaceae (Zygnemaphyceae) da Serra do Cipo, Estado de MinasGerais, Brasil: Tribo Docidieae de Toni. Hoehnea 23(2): 7-20.

Teiling, E. (1948) Staurodesmus, genus novum. Containing monospinous desmids. Bot. Not. 1: 49-83.

Teiling, E. (1967) The desmid genus Staurodesmus. A taxonomic study. Arkiv. f. Bot., II, 6(11): 467-629.

Thomasson, K. (1986) Algal vegetation in North Australian billabongs. Nova Hedwigia 42: 301-378.

Thomasson, K. \& Tyler, P.A. (1971) Taxonomy of Australian freshwater algae. 2. Some planktonic Staurastra from Tasmania, Nova Hedwigia 21: 287-319.

Tyler, P.A. (1970) Taxonomy of Australian freshwater algae. 1. The genus Micrasterias in southeastern Australia. Br. Phycol. J. 5: 211-234.

Viyakornvilas, K. (1974) Some algae in lakes Hume and Mulwala, Victoria. Unpublished B.Sc. (Hons.) thesis, University of Tasmania, Tasmania.

Vyverman, W. (1991) Desmids from Papua New Guinea. Bibliotheca Phycol. 87:1-200

Watts, H. (1887) Some recent additions to our knowledge of microscopic natural history. Victorian Naturalist 3: 133-137.

West, G.S. (1909) The algae of Yan Yean Reservoir, Victoria: a biological and ecological study. J. Linn. Soc. Bot., 39: 1-88.

West, G.S. (1912) Algological Notes V.-IX. J. Bot. 50:79-89.

West, W. \& West, G.S. (1895) A contribution to our knowledge of the freshwater algae of Madagascar. Linn. Soc. J. Bot., II, 5(5): 41-90.

West, W. \& West, G.S. (1905) A monograph of the British Desmidiaceae. Vol. II. (Ray Society: London). West, W. \& West, G.S. (1908) A monograph of the British Desmidiaceae. Vol. III (Ray Society: London). West, W. \& West, G.S. (1912) A monograph of the British Desmidiaceae. Vol. IV (Ray Society: London). West, W., West, G.S. \& Carter, N. (1923) A monograph of the British Desmidiaceae. Vol. V. (Ray Society: London).

Manuscript received 14 December 2000

Manuscript accepted 28 September 2001

\section{Appendix}

Details of the sites in New South Wales sampled, together with lists of taxa collected from them and recorded in this paper.

1. $10 \mathrm{~km}$ west of Collarenebri on the Gwydir Highway, $2^{\circ} 36^{\prime} 13^{\prime \prime S}, 148^{\circ} 28^{\prime} 49^{\prime \prime} \mathrm{E}$. Roadside oligotrophic pond, pH 5.8, 4 Dec 1999.

Closterium didymotocum, Cosmarium biretum, Staurastrum ensiferum forma

2a. Joadja Creek, $11 \mathrm{~km}$ north-west of Berrima, 3424'23"S, 150¹9'21"E, $700 \mathrm{~m}$ asl. Ephemeral, oligotrophic water body, mostly turbid, and with few aquatic plants. Along one edge of the pool is a small stand of Eleocharis sp., pH 7.8, 22 Aug 1992. Closterium intermedium var. intermedium, Cl. ralfsii var. hybridum, Cosmarium blyttii var. blyttii, Co. decemcrenatum, Co. joadjense, Co. quadricrenum, Euastrum insulare var. insulare, Pleurotaenium truncatum var. farquharsonii, Staurastrum striatum, Xanthidium sp. 
2b. Joadja Creek, 13 Oct 1994.

Staurastrum bibrachiatum, S. pseudotetracerum, S. spongiosum forma.

3. Lawson swimming pool, 3343'16"S, $150^{\circ} 25^{\prime} 30^{\prime \prime}$ E. Scraping of gelatinous matter from rock face, $\mathrm{pH}$ 9.0, 8 Aug 1992.

Closterium navicula.

4. Lake Canobolas, $11 \mathrm{~km}$ south west of Orange, $33^{\circ} 17^{\prime} \mathrm{S}, 1^{\circ} 9^{\circ} 02^{\prime} \mathrm{E}$. Scrapings of filamentous algae from concrete dam wall, pH 9.3, 6 Nov 1993.

Closterium navicula.

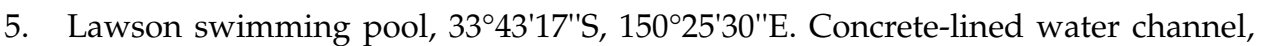
scrapings of gelatinous matter above the waterline, pH 5.8, 30 Dec 1995. Closterium navicula.

6. Off Craigend road, The Oaks, $34^{\circ} 07^{\prime} 00^{\prime \prime} S, 105^{\circ} 33^{\prime} 00^{\prime \prime} \mathrm{E}$. Net sweep through open water of eutrophic watering hole for cattle surrounded by trees, pH 7.6, 20 Jun 1993. Staurastrum simplicius.

7. Lake Gillawarna, Georges Hall, 3354'30"S, 15057'30"E. Net sweep through submerged macrophytes around margin of mesotrophic lake surrounded by recently-built houses, $\mathrm{pH} 8.5,1$ Oct 1994.

Closterium strigosum var. strigosum.

8. Roses Lagoon, near Collector, $34^{\circ} 47^{\prime}$ S, $149^{\circ} 41^{\prime \prime E}$. Myriophyllum aquaticum was squeezed and the resultant liquid saved, pH 7.0, 21 May 1995.

Closterium strigosum var. strigosum .

9. Capertee river (Bogee bridge) 600 metres south of the Rylestone to Glen Alice road, $32^{\circ} 57^{\prime} \mathrm{S}, 150^{\circ} 04^{\prime} \mathrm{E}$. Net sweep through Spikerush Eleocharis sp., pH 7.9, 12 Dec 1995.

Closterium strigosum var. strigosum.

10. Dicks Creek on the Mid Western Highway, $20 \mathrm{~km}$ west of Bathurst, $33^{\circ} 26^{\prime} 30^{\prime \prime} \mathrm{S}$, 149²8'00"E. Net sweep through aquatic macrophytes, pH 7.4, 23 Apr 1993. Closterium strigosum var. elegans.

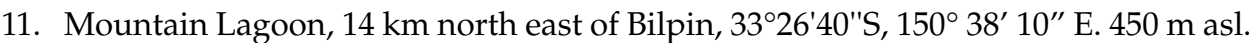
Lagoon, measuring $400 \mathrm{~m} \times 130 \mathrm{~m}$, fed by two small creeks and drained by a third, pH 7.1, 24 Oct 1995.

Actinotaenium cucurbitinum var. subpolymorphum, Closterium subscoticum, Cosmarium dorsitruncatum, Co. margaritatum, Haplotaenium minutum var. cylindricum, Hyalotheca javanica, Micrasterias sp., Pleurotaenium kayei, P. sceptrum, Staurodesmus applanatus, Tetmemorus brebissonii var. tenuissimus.

12. West of The Oaks, $34^{\circ} 07^{\prime} 00^{\prime \prime} \mathrm{S}, 150^{\circ} 32^{\prime} 00^{\prime \prime}$ E. Scraping filamentous algae on inside of concrete cattle drinking trough fed from small farm dam via water pipe, $\mathrm{pH} 7.2$, 29 Aug 1993.

Closterium venus var. westii.

13. Paddys River, 20 km south Berrima, 34³9'34"S, 15007'28'E, $500 \mathrm{~m}$ asl. Net sweep through macrophytes along edge of river bank, pH 5.5, 8 Mar 1995.

Cosmarium depressum var. depressum f. minutum, Co. pachydermum, Euastrum ansatum var. dideltiforme, Euastrum insulare var. silesiacum., E. praemorsum forma, Micrasterias rotata var. rotata f. evoluta, M. zeylanica var. zeylanica, Pleurotaenium eugeneum var. undulatum, Spondylosium pygmaeum var. monile, Staurastrum subradians forma, Staurodesmus convergens var. convergens, Staurodesmus convergens var. ralfsii, Staurodesmus dickiei. var. maximus, Staurodesmus mamillatus, Teilingia excavata, T. granulata. 
14. 400 metres east of Werrington railway station, Werrington, $33^{\circ} 466^{\prime} \mathrm{S}, 150^{\circ} 45^{\prime} \mathrm{E}$. Net sweep through Cumbungi Typha sp. in pond, pH 6.9, 24 Aug 1994.

Pleurotaenium subcoronulatum var. subcoronulatum.

15. $7.7 \mathrm{~km}$ west of Robertson, $34^{\circ} 35^{\prime} \mathrm{S}, 150^{\circ} 33^{\prime} \mathrm{E}$. Net sweep through Spikerush, Eleocharis sp. and Myriophyllum sp. in pond, on hill overlooking larger lake from which peat has been excavated, pH 5.8, 31 Jan 1996.

Cosmarium cymatonotophorum, Xanthidium subhastiferum.

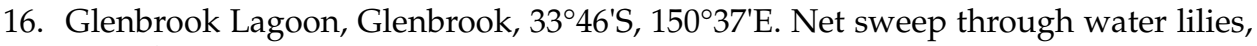
Nymphaea sp., pH 7.3, 12 Sept 1993.

Cosmarium isthmium, Staurastrum gutwinskii f. reductum, Staurodesmus brevispina var. altus.

17. Lagoon alongside Pugh's Lagoon, Richmond, $33^{\circ} 35^{\prime} 45^{\prime \prime}$, $150^{\circ} 44^{\prime} 25^{\prime \prime E}$. Net sweep through water lilies, Nymphaea sp., pH 10.3, 24 Oct 1995.

Cosmarium isthmium.

18. Roadside pond between Warrimoo and Valley Heights, $33^{\circ} 42^{\prime} 55^{\prime \prime S}, 150^{\circ} 35^{\prime} 25^{\prime \prime} \mathrm{E}$. Net sweep through Spikerush Eleocharis sp., pH 7.0, 27 May 1995.

Cosmarium obtusatum.

19. $13 \mathrm{~km}$ north of Jenolan Caves, $100 \mathrm{~m}$ south of Black Range road, $33^{\circ} 45^{\prime} 30^{\prime \prime} \mathrm{S}$, $150^{\circ} 02^{\prime} 30^{\prime \prime E}, 1000 \mathrm{~m}$ asl. Oligotrophic pool $10 \times 12 \mathrm{~m}$ and $30 \mathrm{~cm}$ deep, fed by creek, within swampy area surrounded by pine trees, pH 7.6, 3 Oct 1994.

Cosmarium punctulatum var. minor, C. williamsonii.

20. Near Edith Falls, $33^{\circ} 43^{\prime} 20^{\prime \prime} S, 150^{\circ} 28^{\prime} 18^{\prime \prime E}$. By pipetting green matter on mud of shallow puddle under rock overhang, 5 Sept 1992.

Cosmarium quadratum var. willei.

21. Wentworth Falls lake, $33^{\circ} 42^{\prime} \mathrm{S}, 150^{\circ} 21^{\prime} \mathrm{E}$. Net sweep through emergent grasses around lake margin, pH 6.7, 17 Jan 1994.

Cosmarium quadriverrucosum var. supraornatum.

22. Pond in Alex Trevallion Park, Walgett, $30^{\circ} 02^{\prime} 10^{\prime \prime} S, 148^{\circ} 06^{\prime} 52^{\prime \prime}$ E. Net sweep through Cabomba caroliniana and Myriophyllum sp., ph 7.5, 30 Nov 1999.

Cosmarium quadrum var. sublatum.

23. Pond on side of Archibold Street, 100 metres south of F4 Freeway, Minchinbury, 334ㄱ' ${ }^{\circ}, 150^{\circ} 51^{\prime} E$. Net sweep through aquatic vegetation, pH 6.6, 17 Aug 1994.

Cosmarium regnesi var. montanum, Staurastrum coarctatum var. solitarium, Staurodesmus mucronatus var. mucronatus.

24. Nepean river at Yarramundi crossing near Agnes Banks, 33³7'S, $150^{\circ} 43^{\prime} \mathrm{E}$. By squeezing filamentous algae, pH 9.2, 28 Dec 1993. Cosmarium subundulatum.

25. Lake in Eastlakes, $33^{\circ} 57^{\prime} S, 151^{\circ} 13^{\prime}$ E. Net sweep through submerged aquatic vegetation, pH 6.9, 22 Apr 1993.

Staurodesmus brevispina var. brevispina f. minima. 